\title{
Hepatocyte Injury and Hepatic Stem Cell Niche in the Progression of Non-Alcoholic Steatohepatitis
}

\author{
Diletta Overi ${ }^{1} \oplus$, Guido Carpino ${ }^{2}$, Antonio Franchitto ${ }^{1}$, Paolo Onori ${ }^{1}$ and Eugenio Gaudio ${ }^{1, *}$ \\ 1 Department of Anatomical, Histological, Forensic Medicine and Orthopedics Sciences, Sapienza University \\ of Rome, 00161 Rome, Italy; diletta.overi@uniroma1.it (D.O.); antonio.franchitto@uniroma1.it (A.F.); \\ paolo.onori@uniroma1.it (P.O.) \\ 2 Department of Movement, Human and Health Sciences, Division of Health Sciences, University of Rome \\ "Foro Italico", 00135 Rome, Italy; guido.carpino@uniroma1.it \\ * Correspondence: eugenio.gaudio@uniroma1.it; Tel.: +39-06-4991-8062
}

Received: 24 January 2020; Accepted: 27 February 2020; Published: 2 March 2020

check for updates

\begin{abstract}
Non-alcoholic fatty liver disease (NAFLD) is a chronic liver disease characterized by lipid accumulation in hepatocytes in the absence of excessive alcohol consumption. The global prevalence of NAFLD is constantly increasing. NAFLD is a disease spectrum comprising distinct stages with different prognoses. Non-alcoholic steatohepatitis (NASH) is a progressive condition, characterized by liver inflammation and hepatocyte ballooning, with or without fibrosis. The natural history of NAFLD is negatively influenced by NASH onset and by the progression towards advanced fibrosis. Pathogenetic mechanisms and cellular interactions leading to NASH and fibrosis involve hepatocytes, liver macrophages, myofibroblast cell subpopulations, and the resident progenitor cell niche. These cells are implied in the regenerative trajectories following liver injury, and impairment or perturbation of these mechanisms could lead to NASH and fibrosis. Recent evidence underlines the contribution of extra-hepatic organs/tissues (e.g., gut, adipose tissue) in influencing NASH development by interacting with hepatic cells through various molecular pathways. The present review aims to summarize the role of hepatic parenchymal and non-parenchymal cells, their mutual influence, and the possible interactions with extra-hepatic tissues and organs in the pathogenesis of NAFLD.
\end{abstract}

Keywords: liver; progenitor cell; regeneration; macrophage; disease; fibrosis; lipotoxicity; adipose tissue; atherosclerosis; ductular reaction

\section{Introduction}

Non-alcoholic fatty liver disease (NAFLD) is a chronic liver disease characterized by hepatic fat accumulation in the absence of excessive alcohol consumption, and defined by the presence of steatosis in at least $5 \%$ of hepatocytes [1]. NAFLD is a heterogeneous disease, comprising distinct histological conditions with different prognoses [1]. Non-alcoholic fatty liver (NAFL) is defined as the presence of hepatic steatosis in at least $5 \%$ of the hepatocytes, without evidence of hepatocellular injury in the form of hepatocyte ballooning; non-alcoholic steatohepatitis (NASH) is defined as the presence of at least $5 \%$ hepatic steatosis and inflammation with hepatocyte injury (e.g., ballooning), with or without fibrosis [2]. The term NASH covers a wide spectrum of disease severity, including progressive fibrosis and cirrhosis. Remarkably, both NAFL and NASH can cause hepatocellular carcinoma (HCC) in the presence or absence of liver fibrosis and cirrhosis; in these patients, HCC incidence can vary from $2.4 \%$ to $12.8 \%$ [3].

The global prevalence of NAFLD is currently estimated to be $24 \%$, and it is highly spread in all continents [4]. The prevalence of NAFLD is constantly increasing and, similarly, the rate of NASH has almost doubled in the past years; moreover, NASH is now considered the second most common 
indication for liver transplantation in the USA [4]. Both NAFL and NASH are becoming increasingly prevalent as the epidemics of obesity and diabetes continue to increase. A mathematical model was built to understand how the disease burden associated with NAFLD and NASH will change over time, and the results suggest an increase in the number of cases of advanced liver disease and in liver-related mortality in the coming years, in concert with a global pandemic of obesity [5]. From a clinical perspective, NAFLD is associated with cardiovascular disease, and the two disorders share several cardio-metabolic risk factors [2,6]. NAFLD represents an important issue in the pediatric population, representing the leading cause of chronic liver disease in adolescents and young adults. The prevalence of children obesity is increasing in most regions of the world $[7,8]$, causing a rise in the risk of developing chronic diseases, such as type 2 diabetes, cardiovascular disease, and NAFLD [9].

From an epidemiological and clinical perspective, the increased cardio-metabolic [2] and tumorigenic [3] risk in NAFLD patients seems to depend strongly on the presence of advanced stages of NAFLD, such as NASH, with moderate-to-advanced fibrosis; therefore, basic and translational sciences are making efforts to individuate pathogenetic mechanisms and cellular cross-talks at the basis of NASH evolution and fibrosis development. The present review aims to summarize the role of hepatic parenchymal and non-parenchymal cells and their cross-talks in the pathogenesis of NAFLD, and the possible interactions with extra-hepatic tissues/organs.

\section{Hepatocyte Damage in NAFLD}

\subsection{Hepatocytes in Physiological Turnover and Regeneration}

Hepatocytes represent a cellular population characterized by high proliferative capabilities, which support the physiological renewal of liver parenchyma [10]. Definite subsets of hepatocytes located in a precise position within the liver lobule have been described as main actors in liver homeostasis and regeneration. Around the centrilobular vein, subpopulations of diploid Axin $2^{+}$[11] and Lgr5 ${ }^{+}$[12] hepatocytes have been individuated; both these subpopulations are characterized by self-renewal properties and their progeny, during homeostasis, can generate pericentral hepatocytes. However, the role of these subpopulations in generating periportal hepatocytes is controversial $[13,14]$. In fact, at periportal zone, hepatocyte subpopulation expressing Sox9 [15] or Mfsd2a [16] were identified and individuated as major contributors in the regeneration of zone 1 hepatocytes during injury-induced regeneration.

Recently, a rare subset of hepatocytes that expresses high levels of telomerase and distributed throughout the liver lobule were demonstrated to be able to regenerate hepatocytes in all lobular zones [10]. Similarly, recent evidence have further disclosed the dynamics of hepatocyte replication in physiological turnover and in regeneration after injury, demonstrating that most hepatocytes throughout the lobule participate in maintaining the hepatocyte mass and proliferate to regenerate it, with diploid cells holding a growth advantage over polyploid ones [12,13,17,18].

\subsection{Morphological Alterations in Hepatocytes}

The morphological hallmark of NAFLD is the presence of hepatic steatosis, i.e., the accumulation of fat within the hepatocytes (Figure 1) $[19,20]$. In NAFLD patients, usually, large fat droplets (i.e., macrovesicular steatosis) are observed inside the hepatocytes but, occasionally, smaller areas of microvesicular steatosis can be found [19]. Pericentral hepatocytes, compared to periportal ones, are the most subjected to steatosis, due to their specific role in fat metabolism [20]; as a consequence, in early phases of NAFLD, hepatic steatosis is mainly located around the centrilobular vein, extending towards portal tracts as the entity of steatosis increases and hepatic zonation is lost $[19,20]$. The continuous exposure of hepatocytes to cellular stressors leads to the emergence of specific histological features of NASH, such as hepatocellular ballooning and Mallory-Denk Bodies (MDBs, or Mallory's hyaline), which also represent negative prognostic indexes [19,21]. Ballooned hepatocytes are larger than normal ones, and are characterized by rarified, irregular cytoplasm, and by the loss of positivity for 
cytokeratins (CK) 8 and 18 [19,22]. MDBs are eosinophil accumulations of ubiquitinated proteins within the cytoplasm of hepatocytes, and can be identified in routine stains (especially in ballooned hepatocytes) or highlighted by immunohistochemistry for bound proteins (i.e., ubiquitin or p62) [19].
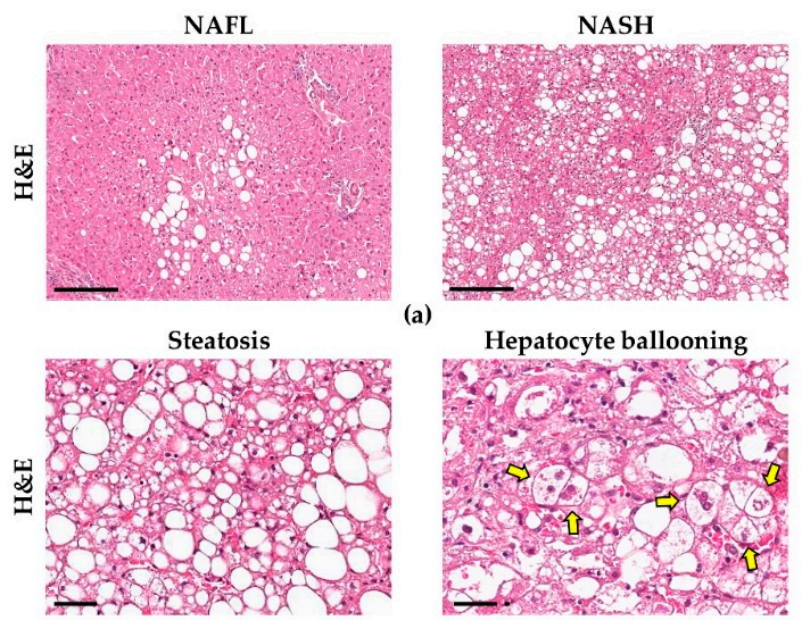

(a)
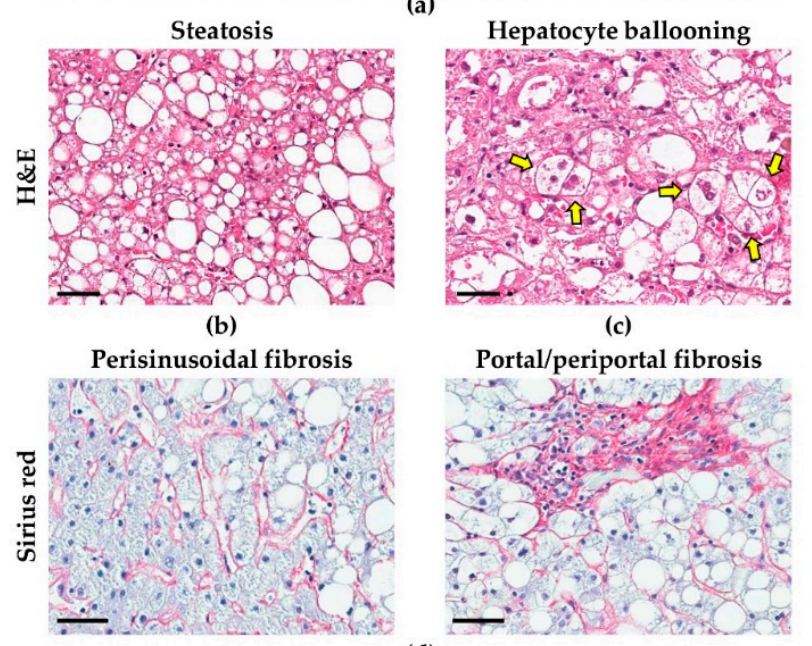

(d)

Figure 1. Histo-morphological features of non-alcoholic fatty liver disease (NAFLD). The progression from simple steatosis (non-alcoholic fatty liver-NAFL) to non-alcoholic steatohepatitis (NASH) (a) is characterized by increased hepatic steatosis (b) and inflammation, accompanied by the emergence of specific histological features, such as hepatocellular ballooning (arrows in c). As disease advances, liver fibrosis develops (d). H\&E: hematoxylin and eosin; scale bars: $200(\mathbf{a}), 50(\mathbf{b}, \mathbf{c})$ and $100 \mu \mathrm{m}(\mathbf{d})$. Images obtained from liver biopsies of patients affected by NAFLD.

\subsection{Lipotoxicity in Hepatocytes}

Lipotoxicity is considered the cellular damage due to the accumulation of abnormal lipid compounds in the cell, leading to the formation of reactive species of oxygen (ROS) [22,23]. NAFLD patients are characterized by an increased load of free fatty acids (FFAs) in the liver, which can be due both to increased lipolysis from adipose tissue but also to de novo lipogenesis in hepatocytes [24-30]. Insulin resistance has a prominent role in these processes by favoring an increased lipolytic response to the meal, and by inducing the expression of lipogenic pathways in the liver $[24,25,27,31,32]$. In the liver, FFAs are metabolized by beta-oxidation in mitochondria, or esterified as triglycerides (TGs), and either secreted within very-low-density lipoproteins (VLDL) or stored in lipid droplets leading to hepatic steatosis [25]. With the progression toward NASH, hepatocytes become increasingly sensitive to damage and incapable to respond to injury due to the accumulation of toxic lipid metabolites, the production of ROS, and the dysfunction of detoxification responses [23,26]; in parallel, VLDL lipolysis and production are decreased, leading to further accumulation of TGs in hepatocytes [33,34]. One of the main effectors of damage-induced response is c-Jun N-terminal kinase (JNK). JNK is a member of the mitogen-activated protein kinase (MAPK) family and represents the downstream effector for several signaling pathways leading to an increased expression of pro-apoptotic and pro-inflammatory transcription factors [25,35]. NASH patients are characterized by increased phosphorylation (i.e., activation) of JNK $[23,36,37]$, which can be due both to a direct effect of FFAs, or to the activation of 
nuclear factor- $\mathrm{kB}$ (NF-kB) pathway [26,38]. Upregulation of JNK pathway also leads to inactivation of insulin receptor, aggravating insulin resistance in hepatocytes [24,26].

Genome-wide studies have been able to identify genetic determinants of NAFLD. Among these, the single nucleotide polymorphism in residue 148 (I148M, rs738409) in human patatin-like phospholipase domain containing 3 (PNPLA3) gene, encoding the protein adiponutrin, has been recognized as one of the strongest genetic factors leading to NAFLD development $[39,40]$. Interestingly, the relationship between PNPLA3 variant and NAFLD development was independent to metabolic risk factors and lipid profile [40]. Although the basis of this association has not been fully elucidated, PNPLA3 variant carriers are characterized by reduced hydrolasic activity of adiponutrin, leading to increased lipid content in the liver [41,42]. Interestingly, PNPLA3 I148M carriers are characterized by worse histological depicts, with steatosis occurring in periportal hepatocytes also in early-grade disease [43-45].

\subsection{Endoplasmic Reticulum Stress and Mitochondrial Dysfunction in NAFLD}

Normal hepatocytes are characterized by an extensive endoplasmic reticulum (ER), and this organelle can be severely affected in course of chronic metabolic unbalance and cellular stress [28,46-49]. De novo lipogenesis occurs in ER and is regulated by membrane proteins sterol regulatory element-binding proteins (SREPB1c and SREPB2, for fatty acids and cholesterol respectively) and related pathways $[24,25,38,46]$. In presence of insulin resistance, these proteins are upregulated, leading to increased lipogenesis and further lipotoxicity $[24,25,28,38,50]$. Moreover, the hepatic accumulation of fat can lead to altered composition of ER membrane, leading to impaired functionality $[46,51,52]$.

All membrane and secreted proteins (e.g., lipoproteins) are synthesized and/or assembled on the ER, which represents a highly active task in the hepatocyte; in this context, injured hepatocytes are characterized by an increase in misfolded proteins which accumulate in the cytoplasm (e.g., MDBs), can overload the ER and, subsequently, trigger the so-called unfolded protein response (UPR), a protective pathway which is aimed to reduce damage to the cell; however, when extensive or chronic damage occur, this response can be overwhelmed and, in turn, lead to cell death $[24,46,53]$. ER is endowed with stress sensors that respond to injury signals leading to UPR activation; among these, the transmembrane protein inositol-requiring enzyme $1 \alpha$ (IRE1 $\alpha$ ) plays a crucial role, interacting with different pathways in the cell [54]. By binding to misfolded proteins or lipids, it can phosphorylate JNK and IкB (upstream of NF- $\mathrm{KB}$ pathway), leading to reduced insulin sensitivity and pro-inflammatory pathway activation $[24,38,55]$. Moreover, ER stress can lead to increased inflammasome pathway activation and further hepatocyte injury, eventually leading to a shift towards pro-apoptotic signaling pathways $[24,28,48,56-60]$.

Hepatocytes are characterized by a high number of mitochondria. Under normal conditions, mitochondria are the major site of ROS formation in the cell, with $\sim 2 \%$ of consumed $\mathrm{O}_{2}$ converted in ROS [61,62]. Moreover, mitochondria can also furnish intracellular signals leading to adaptation of the cell to the environment [61]: in the first stages of NAFLD, mitochondria increase their activity in response to the rising lipid levels in the hepatocytes, with a protective effect $[23,25]$. In this context, the exposure to oxidative stress triggers the adaptation of mitochondria (i.e., mitochondrial remodeling), with morphological modifications occurring through mitochondrial fission and fusion, and with variations in energy expenditure and gene expression [63].

According to these observations, mitochondria undergo pathological modifications in course of NAFLD, especially when progressing towards NASH, with impairment in adaptive capabilities, reduced ATP production and increased oxidative stress in the cell [24,25,35,63-68]. Moreover, ultrastructural damage to the mitochondria characterizes liver biopsies from NASH patients $[69,70]$. In particular, damaged hepatocytes show the presence of enlarged mitochondria, characterized by the loss of cristae and by the presence of crystalline inclusions [66,70,71]; in some cases, megamitochondria $(3-10 \mu \mathrm{m}$ in diameter) can be found, being also visible in Masson trichrome stain as red inclusions within the hepatocytes $[19,72,73]$. The formation of megamitochondria likely involves unbalanced mitochondrial division and fusion, and recent data in rodent NASH models indicated that extreme mitochondrial size 
contributes to hepatocyte dysfunction [74]; moreover, the increased number of mitochondria observed in NASH seems to be due mainly to defects in the removal of damaged organelles via autophagy (in this case, mitophagy) than to increased mitochondrial biogenesis $[23,25,60]$. Several mechanisms might be involved in mitophagy alteration in NAFLD [75], such as the impairment of a parkin-independent mitophagy pathway, based on p62-regulated mitochondrial ubiquitination by Keap1 and Rbx1 [74].

In NAFLD patients, products of lipid metabolism lead to damage to mtDNA and mitochondrial respiratory chain (MRC) proteins $[23,25,67,74]$; moreover, the binding of activated JNK to MRC complexes leads to increased ROS formation [25,35]. This aspect is particularly evident in the progression towards NASH, were increased ROS release by mitochondria is accompanied by reduced catalase activity, leading to impaired detoxification and further damage to the organelle $[23,25,76,77]$. Moreover, excess cholesterol can lead to a loss of glutathione by mitochondria, aggravating the reduced state of the cell [38] and leading to altered beta-oxidation and lipotoxicity [24]. Finally, hepatocyte necrosis could lead to the release of mitochondria-derived danger associated molecular patterns (DAMPs), which in turn could activate NLRP3 (NACHT, LRR and PYD domains-containing protein 3) inflammasome pathway (see also the following section) [78-80].

\subsection{Hepatocyte Autophagy and Apoptosis in NAFLD}

Damaged organelles or proteins are usually removed by autophagy $[60,81,82]$. To do so, they are included in the autophagosome, a vacuolar structure which later merges to lysosomes (i.e., autolysosomes), where they are degraded. This catabolic process is aimed to preserve cellular homeostasis by removing non-functional structures and repurposing the product of their degradation inside the cell [83]. Autophagy also plays a role in the mobilization of FFAs from lipid droplets after starvation [84-86]; by contrast, an abnormal increase in intracellular lipid could impair autophagic clearance in hepatocytes [84]. This reverse relationship could contribute to the development of a negative loop in which decreased autophagy promotes lipid accumulation that then further suppresses autophagic function, additionally increasing lipid retention [84,87-93]. Reduced autophagic function could also take part in the accumulation of MDBs in hepatocytes, perpetrating ER stress [83,94,95]. Interestingly, long-term insulin resistance can impair autophagy by reduced expression of transcriptional factors related to autophagic pathways; at the same time, reduced autophagy leads to an increased oxidative damage of the cell, for example by reduced clearance of non-functional mitochondria and increased expression of JNK pathway elements, thus further participating to the vicious cycle that perpetrates pathological processes in the cell $[96,97]$.

The accumulation of different cellular stressors leads to the progression from a state of sublethal injury to, eventually, cellular death [22,24]. Controlled cell death (i.e., apoptosis) is a cellular process aimed to eliminate altered cells in order to preserve the integrity of the tissue; extrinsic (Fas/perforin-mediated) or intrinsic (e.g., ER stress) signaling can reach the mitochondria, releasing cytochrome $\mathrm{c}$ into the cytoplasm and leading to cleavage (and subsequent activation) of the protease family of caspases, with terminal apoptosis induction [24,98-103]. In NAFLD, multiple intracellular signaling pathways have been proved to trigger apoptosis in hepatocytes (for a detailed review on this topic, see Kanda et al. [104]). Accordingly, when progressing towards NASH, hepatocytes increasingly undergo cell cycle arrest and express apoptosis markers such as caspases and Fas receptors [102,105-110]. Interestingly, ballooned hepatocytes represent "undead" hepatocytes, characterized by resistance to apoptotic injury; this is due to a reduced expression of caspases in a Hedgehog-mediated signaling which, however, leads to the activation of pro-inflammatory and pro-fibrogenetic pathways [22,111-115]. In this context, uncontrolled cell death (i.e., necrosis) can occur as disease progresses; this type of cellular death is characterized by cellular damage with release of DAMPs, leading to damage to neighboring cells, to an inflammatory response in immune cells, and to pro-fibrogenetic loops [25,98].

In summary (Table 1), the chronic hepatocellular damage occurring in NAFLD leads to a severe impairment of the cellular mechanisms that are responsible for the clearance of unhealthy and 
dysfunctional cells; this triggers a tissue response that involves the other cell populations within the liver, and which will be described in the following sections.

Table 1. Modifications in hepatocytes in NAFLD.

\begin{tabular}{|c|c|}
\hline $\begin{array}{l}\text { NON-ALCOHOLIC } \\
\text { FATTY LIVER }\end{array}$ & NON-ALCOHOLIC STEATOHEPATITIS \\
\hline $\begin{array}{ll}\text { - } & \text { Hepatic steatosis } \\
\text { - } & \text { Increased fat intake } \\
\text { - } & \text { Insulin resistance } \\
\text { - } & \text { Lipolysis from adipose tissue } \\
\text { - } & \text { De novo lipogenesis } \\
\text { - } & \text { Lipopolysaccharides (LPS) localization (low) }\end{array}$ & $\begin{array}{ll}\text { - } & \text { Lipotoxicity } \\
\text { - } & \text { Hepatocellular ballooning } \\
\text { - } & \text { Endoplasmic reticulum stress } \\
\text { - } & \text { Mitochondrial alterations } \\
\text { - } & \text { Oxidative stress } \\
\text { - } & \text { Damaged organelles/proteins } \\
\text { - } & \text { Hepatocyte apoptosis/necrosis } \\
\text { - } & \text { LPS localization (high) } \\
\end{array}$ \\
\hline
\end{tabular}

\section{Hepatic Stem/progenitor Cells (HpSCs)}

\subsection{HpSCs are Involved in the Liver Regenerative Response}

Hepatic Stem/progenitor Cells (HpSCs) are bipotent progenitor cells, capable to differentiate into mature hepatocytes and cholangiocytes $[116,117]$. HpSCs are characterized by small size, scant cytoplasm, and an oval nucleus; in liver samples, they can be uniquely individuated by their expression of biliary cytokeratins (e.g., CK7/19) and conventional stem cell markers (e.g., Sox9, CD44, CD133, Epithelial Cell Adhesion Molecule-EpCAM, and Neural Cell Adhesion Molecule-NCAM) [118,119]. HpSCs are facultative stem cells, which are quiescent during physiological turnover of the organ but are activated in acute and chronic liver injuries [120]. HpSCs respond to various stimuli and, once activated, they generate a peculiar morphological tissue response characterized by the appearance of the so-called ductular reaction (DR) [121-123]. $\mathrm{DR}$ is constituted of reactive ductules, twisting strings of $\mathrm{CK} 7 / 19^{+}$cells without a distinct lumen, and it can show a heterogeneous and highly variable phenotype, which is influenced by the regenerative needs due to the specific disease etiology $[119,124]$.

The actual contribution of the HpSC niche to the renewal of liver parenchyma is at the center of active debate in the scientific community. Using different lineage tracing approaches, it has been observed only a marginal contribution of HpSC in several models of hepatocellular injury [125-127]. However, other eminent studies indicated this biliary epithelial compartment as an important source of newly-formed hepatocytes in models where mature hepatocyte proliferation was experimentally impaired [128,129]. Particularly, a progressive HpSC differentiation into mature, functional hepatocytes was observed in genetic mouse models characterized by the induction of apoptosis in $98 \%$ of hepatocytes [130] or by the specific blocking of crucial elements of hepatocyte replication pathways [128,129]. Furthermore, elegant models implying long term injury acknowledged the occurrence of DR/HpSC activation as a crucial prerequisite for hepatocyte repopulation [86,131]. Overall, when interpreted together, these evidences indicate that HpSCs represent a quiescent stem cell compartment, which is recruited in course of high-degree and/or long-term liver injury characterized by severe impairment of hepatocyte replicative capabilities and, in the appropriate conditions, can drive a regenerative response allowing liver regeneration.

\subsection{HpSCs and Their Niche}

HpSCs are supported by a specialized anatomical and functional niche, composed of portal myofibroblasts, hepatic stellate cells (HSCs) and resident macrophages (i.e., Kupffer cells) (Figure 2) [132-134]. A crucial function of the niche is the production of several humoral factors, which support HpSC behavior and influence their activation/differentiation state [135]. The main signaling pathways 
involved in HpSC niche are represented by Notch and WNT systems. HSCs and myofibroblasts can secrete a variety of Notch ligands, which have the role of maintaining HpSCs in a biliary phenotype $[119,132,136]$. Conversely, the presentation of WNT ligands to HpSCs induces their proliferation and their commitment to the hepatocyte fate $[132,135,137]$. Macrophages are the main source of WNT ligands within the niche $[138,139]$.
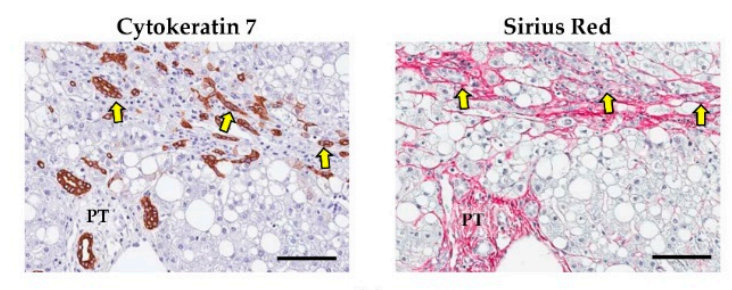

(a)
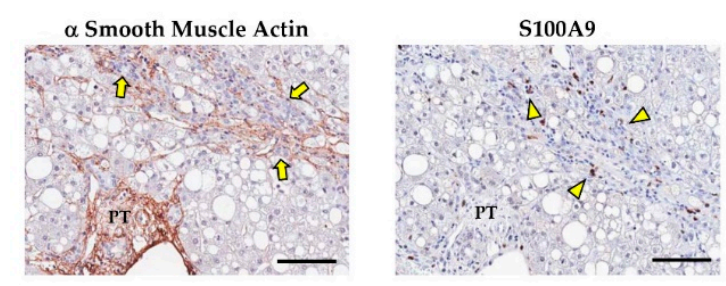

(b)

Figure 2. Ductular reaction (DR), myofibroblasts, and portal macrophages in non-alcoholic fatty liver disease (NAFLD). (a) As NAFLD progresses from simple steatosis to non-alcoholic steatohepatitis (NASH), a prominent DR emerges (arrows in image on the left) and is associated with portal/periportal fibrosis, as evidenced in Sirius Red stains (arrows in image on the right). (b) The expansion of DR is associated with the activation of ( $\alpha$ smooth muscle actin-positive) hepatic stellate cells and portal myofibroblasts (arrows), and the recruitment of pro-inflammatory $\left(\mathrm{S} 100 \mathrm{~A} 9^{+}\right)$macrophages (arrowheads), which participate in portal/periportal fibrogenetic pathway. PT: portal tract. Scale bars: $100 \mu \mathrm{m}$. Images obtained from liver biopsies of patients affected by NAFLD.

In turn, HpSCs themselves can produce factors that regulate the activation state of non-parenchymal cells within the niche [134]; for instance, HpSC proliferation activates portal myofibroblast/HSC pool by the secretion of Hedgehog ligands, osteopontin (OPN), and transforming growth factor (TGF)- $\beta 1$ [140]. In liver disease, this can result in the induction of collagen deposition [141,142], leading to fibrogenesis and disease stage progression [121,143].

\subsection{HpSCs and Their Involvement in NAFLD Progression}

In NAFLD, DR has been extensively studied and it has been correlated with the severity of damage and the progression of liver disease (Figure 3). In these patients, a prominent DR characterizes both adult [144] and pediatric [110] populations affected by advanced stages (i.e., NASH and NASH-fibrosis). Interestingly, DR extent has been correlated with hepatocyte apoptosis, cell cycle arrest, and oxidative stress; thus, indicating that HpSC activation is triggered by progressive hepatocyte cell injury [110]; moreover, in NAFLD, DR is associated with the emergence from reactive ductules of cells with signs of hepatocyte differentiation $[110,144]$. 


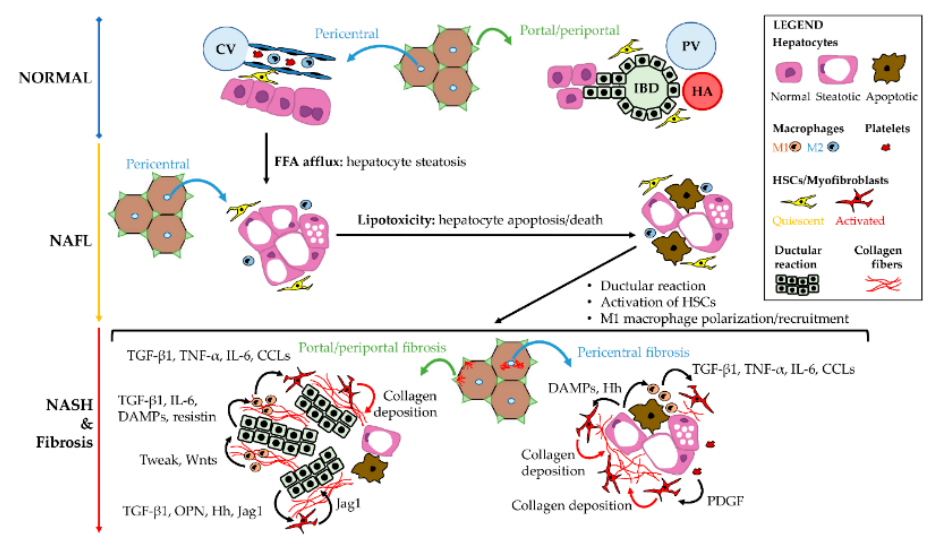

Figure 3. Cellular cross-talks in the pathogenesis of non-alcoholic fatty liver disease (NAFLD). The increase of free-fatty acid (FFA) afflux to the liver determinates hepatocyte steatosis (non-alcoholic fatty liver - NAFL); subsequently, the accumulation of abnormal lipid compounds in the hepatocytes causes lipotoxicity, leading to hepatocyte damage, apoptosis and death. Hepatocyte lipotoxicity triggers M1 macrophage recruitment and lobular inflammation (i.e., steatohepatitis: NASH) and, then, pro-fibrogenetic pathways. In pericentral zone, the activation of hepatic stellate cells (HSCs) and the M1 macrophage polarization trigger perisinusoidal fibrosis. At periportal location, ductular reaction emerges and drives the activation of local myofibroblast pools together with M1 macrophage recruitment. The main molecular factors implied in local cellular cross-talks are summarized in the scheme.

Remarkably, there is a strict correlation between DR extension and the entity of portal fibrosis and portal inflammation [110,144-146]. This correlation is due to the cross-talks between HpSC and non-parenchymal cells (i.e., myofibroblasts and macrophages) within the liver [134], as further discussed later in this review (Figure 3). The activation of HpSC niche could have a significant role in influencing the clinical spectrum of NAFLD, independently to the severity of hepatocyte damage [44]. In NAFLD, pediatric patients also suffering from obstructive sleep apnea syndrome are characterized by higher activation of $\mathrm{HpSC}$ niche, with nocturnal hypoxemia being an independent predictor of HpSC activation [147]. Moreover, a peculiar HpSC activation pattern can be observed in patients carrying PNPLA3 I148M variant; the presence of PNPLA3 variant was associated with a more prominent DR and recruitment of cellular components of the niche (i.e., activated myofibroblasts and pro-inflammatory macrophages), independently to the disease grade and stage [44].

\section{Non-Parenchymal Cells: Supporting the HpSC Response in NAFLD}

\subsection{Hepatic Stellate Cells and Portal Myofibroblasts: Fibrogenetic Pathways in NAFLD}

The source of fibrillar collagen in pathological conditions is represented by HSCs and portal myofibroblasts [148,149]. HSCs are perisinusoidal cells located within the space of Disse. In homeostatic conditions, HSCs are quiescent cells [150] and their main functional role is Vitamin A storage; however, in the course of liver injuries, HSCs can trans-differentiate into activated myofibroblast-like cells [151-153].

In normal conditions, the liver is characterized by a unique organization of the extracellular matrix (ECM) within the space of Disse: the cords of hepatocytes that constitute the liver lobule are lining on a discontinuous basal membrane, accompanied by few reticular ECM fibers (e.g., type IV collagens, laminin, and perlecan); differently, fibrillar collagens (mostly type I, III, and V) are mainly located around the portal tract, where they constitute a more dense fibrous network [154-156]. However, the tissue response to injury and the activation and trans-differentiation of HSCs lead to a complete remodeling of the ECM, from both a qualitative and a quantitative point of view [156,157]. In particular, the deposition of collagens increases, with a relevant proportion of fibrillar collagens, and ECM proteins such as fibulin-5, vitronectin and lumican [149,157-161]. This becomes even more apparent as disease 
progresses, as demonstrated by an interesting study of liver transcriptome of NAFLD patients which has revealed the upregulation of genes related to ECM organization in NASH compared to NAFL patients, mediated by the activation of Hedgehog pathway [162].

Traditionally, liver fibrosis (especially in advanced stages) has been considered a "static" condition, with an inevitable progression towards liver cirrhosis. In this context, as NAFLD progresses, the remodeling of fibrotic tissues appears to be impaired due to a reduced intrinsic activity of matrix metalloproteinases (MMPs) and to an increased production of tissue inhibitors of metalloproteinases (TIMPs), with an altered ECM balance that favors the accumulation of pro-fibrogenetic ECM compounds [160,163-165]. However, several clinical trials in subjects with NAFLD have shown how the improvement of clinical status is accompanied by an amelioration of histological depicts, including a significant reduction of fibrosis stage [166-169]. Moreover, a constant remodeling of the fibrous tissues occurs, releasing fragments of ECM proteins (with the collagen III fragment pro-C3 being one of the most validated ones $[170,171])$, which can be isolated from the serum of NAFLD patients and can help identify, in particular, patients in advanced fibrosis stages $[157,159,172,173]$.

The patterns of liver fibrosis vary according to the specific disease aetiology [121,174]; in chronic viral hepatitis, hepatocyte damage is mostly located in zone 1 within the liver lobule; the consequent piecemeal necrosis triggers periportal HSCs and portal myofibroblasts; thus, determining portal expansion followed by periportal fibrosis, septal (bridging) fibrosis, and cirrhosis [175]. A similar portal/periportal pattern is observed in biliary fibrosis, which is due to bile duct damage and cholestasis, as in primary biliary cholangitis and primary sclerosing cholangitis [132]. Differently, in alcoholic liver disease or in NAFLD, primary damage involves pericentral (i.e., zone 3) hepatocytes, and, thus, fibrosis conventionally starts with a centrilobular/perivenular distribution and perisinusoidal fibrosis. More recently, two distinct patterns of liver fibrosis have been individuated in NAFLD [174]; in pediatric patients with NAFLD, a portal/periportal fibrosis pattern is predominant [110]. In adults, a centrilobular pattern of perisinusoidal fibrosis is typically observed; however, portal/periportal fibrosis is also described [44].

Portal fibrosis has been pathogenically associated to the activation of HpSC niche and DR appearance, since HpSCs can activate fibrogenetic cells by the secretion of numerous signals, including Hedgehog ligands, TGF- $\beta$, TNF-like weak inducer of apoptosis (TWEAK), and platelet-derived growth factor (PDGF) [121]. In keeping with that, DR is correlated with fibrosis and HSC activation both in adult and in pediatric patients [110]. Interestingly, adult patients carrying I148M PNPLA3 variant are characterized by the loss of a predominant pericentral pattern of liver damage and fibrosis, which is associated to increased DR extent independently to other clinical and histological parameters [44].

\subsection{Liver Macrophages and Their Role in Influencing Fibrogenesis and HpSC Response}

The liver macrophage pool is composed of heterogeneous populations. Resident macrophages (Kupffer cells: KCs) are located within hepatic sinusoids [176] and, in physiological conditions, are involved in tissue homeostasis, phagocytosis of cellular debris, iron homeostasis and in the modulation of immune response [176]; indeed, KCs regulate dendritic cell and T lymphocyte activation [177-179]. On the other hand, infiltrating monocytes can derive from circulating monocytes [176].

In NAFLD, several experimental evidences have indicated that the macrophage pool has a pivotal role in inflammatory processes and in NASH development, with the emergence of pro-inflammatory macrophages (i.e., classically activated macrophages, or M1 polarized). In mouse models, the depletion of KCs determined the marked reduction of hepatic inflammation in NASH $[180,181]$. Resident KCs can accumulate large amounts of toxic lipids and transform into foam cells [176]; lipid loaded macrophages are committed to a M1 phenotype and are active in the production of pro-inflammatory cytokines such as tumor necrosis factor (TNF)- $\alpha$ [182]. Moreover, M1 macrophages express toll-like receptor 4 (TLR4), which is implicated in intracellular signaling and response to various pathogenetic stimuli such as 
DAMPs and pathogen-associated molecular patterns (PAMPs), such as lipopolysaccharides (LPS). Binding of ligands to TLR4 induces the activation of nuclear factor (NF)-KB, stimulating cytokine production and proliferation of macrophages [183]. In NAFLD, the activation of TLR4 in macrophages following hepatocyte necrosis and LPS translation within the liver contributes to local inflammation and correlates with disease progression and DR extent [184].

Conversely, in mouse models, the induction of the M2 activation state (i.e., alternatively-activated macrophages) in resident macrophages is associated with impaired M1 response [185]; macrophages on M2 spectrum ranges are able to promote M1 apoptosis by interleukin (IL)-10 secretion; thus, limiting liver injury and NASH progression [185]. In parallel, NASH is characterized by an enhanced recruitment of circulating monocytes to the injured liver, sustained by KC-derived cytokines; recruited cells further increase the M1 macrophage pool within the liver [176] with a reduction in the M2 compartment [184]. Interestingly, portal infiltration of macrophages seems to be an early event in human NAFLD and predicts progressive disease [145]. Among cytokines, chemokine (C-C motif) ligand 2 (CCL2, or monocyte chemotactic protein 1) mainly contributes to the recruitment of circulating monocytes into the inflamed liver, and its inhibition can impair monocyte recruitment and prevent NASH progression [186-188]. In humans, an increased number of CD68 ${ }^{+}$KCs was observed in biopsy samples of patients with more severe NAFLD $[183,184]$. In children with NAFLD, the number of macrophages increased both in lobular and portal zones; in parallel, a progressive switch to a M1 activation state was observed, in correlation with disease stage [137]. Portal infiltration of macrophages also seems to be an early event in human NAFLD and predict progressive disease [145].

Liver macrophage pool orchestrates several interactions and cross-talks among resident or recruited cells; thus, driving inflammatory processes and fibrogenesis during the progression of NAFLD [189]. The spectrum of liver macrophage activation is also relevant for fibrosis progression in NAFLD. Liver macrophage on the M1 spectrum ranges could trigger HSC trans-differentiation, and their depletion in mouse models attenuates the fibrosis progression [189]. From a molecular point of view, macrophages can i) activate HSCs by releasing TGF- $\beta$ and other pro-fibrogenetic cytokines, ii) promote HSC survival and TIMP-1 production via TNF- $\alpha$ and IL-1 secretion $[190,191]$, and iii) promote HSC migration via the secretion of CCL2, CCL3-5, CCL7, and CCL8 [192].

Liver macrophages can have a role in regulating liver regeneration by influencing HpSCs niche [193]. Among the variety of cytokines produced by macrophages, TWEAK is a potent mitogen for HpSCs [138,139]. Furthermore, macrophages are able to secrete WNT ligands (e.g., Wnt3a), thus activating canonical Wnt pathway in HpSCs and triggering their commitment towards hepatocyte fate $[135,137]$. The Wnt3a production by macrophages is determined by an efficient phagocytosis of the hepatocyte debris [135]. In turn, proliferating HpSCs could secrete a variety of compounds which influence macrophage activation state [141,142]. Indeed, adipocytokines (i.e., adipose tissue cytokines) could represent an intriguing tool in the cellular cross-talks among HpSCs and liver macrophages [110]. In pediatric NASH, HpSCs down-regulate their adiponectin production and, on the other hand, up-regulated their expression of resistin in correlation with progression towards NASH and fibrosis [194]. Adiponectin exerts anti-inflammatory properties and is able to ameliorate inflammation when administered in experimental NASH [195,196]. By contrast, resistin is a mediator of hepatic inflammation and macrophage activation and its administration in rats significantly worsens inflammation [197] by increasing macrophage recruitment and proinflammatory cytokine expression $[195,197]$.

\subsection{Re-Shaping HpSC Niche as a Therapeutic Approach in NAFLD Patients}

Therapies able to improve liver histology in NAFLD patients have also a significant effect on the HpSC niche, supporting its role in disease progression.

In a clinical trial on pediatric patients with NAFLD, the administration of docosahexaenoic acid (a polyunsaturated fatty acid) has been proved to improve liver steatosis and insulin sensitivity. In parallel, docosahexaenoic acid administration determined a re-shaping of HpSC niche by also modulating 
macrophage activation states $[137,169,198]$. Remarkably, docosahexaenoic acid treatment determined a reduction in HpSC number and a macrophage polarization towards an anti-inflammatory (M2) phenotype; these changes correlated with amelioration in liver histology. Furthermore, macrophage polarization state towards M2 was correlated with the reduction of serum inflammatory cytokines, with increased macrophage apoptosis, and with the up-regulation of macrophage Wnt3a expression; in turn, macrophage Wnt3a expression was correlated with $\beta$-catenin phosphorylation in hepatic progenitor cells and signs of commitment towards hepatocyte fate.

Interestingly, the combined therapy with docosahexaenoic acid and vitamin D in pediatric NAFLD patients lead to the reduction in myofibroblast activation and fibrogenesis in correlation with histological depicts [169]. Finally, in obese patients affected by NAFLD, laparoscopic sleeve gastrectomy has been proved to determine the amelioration in NAFLD disease stage and grade; this improvement was associated with the reduction of hepatocyte senescence, HpSC activation and recruitment of cellular components of the niche [166].

In sum (Table 2), HpSC niche activation represents a key factor in the local response to injury in NAFLD patients, actively participating in modulating inflammation and fibrogenetic processes. The development of integrated therapies for NAFLD/NASH should consider the signaling pathways acting in HpSC niche, in order to achieve the optimal tissue remodeling that is required to prevent disease progression.

Table 2. Phenotypical changes within Hepatic Stem/progenitor Cell niche in NAFLD.

\begin{tabular}{|c|c|c|}
\hline & $\begin{array}{l}\text { NON-ALCOHOLIC } \\
\text { FATTY LIVER }\end{array}$ & $\begin{array}{l}\text { NON-ALCOHOLIC } \\
\text { STEATOHEPATITIS }\end{array}$ \\
\hline Hepatic stem/progenitor cells & - Mostly quiescent & $\begin{array}{ll}\text { - } & \text { Activation } \\
\text { - } & \text { Ductular reaction } \\
\text { - } & \text { Cytokine release } \\
\text { - } & \text { Signaling molecule release }\end{array}$ \\
\hline $\begin{array}{l}\text { Hepatic stellate cells \& portal } \\
\text { myofibroblast pool }\end{array}$ & $\begin{array}{ll}\text { - } & \text { Mostly quiescent } \\
\text { - } & \text { Reticular extracellular matrix } \\
\text { (ECM) production } \\
\text { - } \quad \text { Initial perisinusoidal fibrosis }\end{array}$ & $\begin{array}{ll}\text { - } & \text { Activation } \\
\text { - } & \text { Fibrillar ECM proteins } \\
\text { - } & \text { Progressive fibrosis } \\
\text { - } & \text { Signaling molecule release }\end{array}$ \\
\hline Liver macrophage pool & $\begin{array}{l}\text { Lobular macrophages } \\
-\quad \uparrow \text { Lobular macrophages } \\
\text { - } \quad \downarrow \text { Lobular M2 macrophages } \\
\text { Portal macrophages } \\
\text { - } \quad \text { No modifications }\end{array}$ & $\begin{array}{l}\text { Lobular macrophages } \\
\text { - } \quad \uparrow \mathrm{M} 1 \text { lobular macrophages } \\
\text { Portal macrophages } \\
\text { - } \quad \uparrow \text { Portal macrophages } \\
\text { - } \quad \uparrow \mathrm{M} 1 \text { portal macrophages } \\
\text { - } \quad \downarrow \mathrm{M} 2 \text { portal macrophages }\end{array}$ \\
\hline
\end{tabular}

\section{Interaction of Liver Cellular Compartments with Extra-Hepatic Organs}

The clinical management of NAFLD patients has demonstrated how this disease should be considered in a broader scenario and how patients should be framed with a multi-disciplinary approach, given the mutual influence between NAFLD and the other organ diseases (e.g., heart failure, atherosclerosis, arterial hypertension, diabetes, chronic kidney disease, gut dysbiosis, obesity, and metabolic syndrome) [6]. Although these clinical manifestations are now well recognized in NAFLD and led to changes in international guidelines recommendation for patient management [1], the mechanisms of these systemic interactions are less known, both at cellular and molecular levels. However, it is now evident that factors coming from the gut (i.e., bacterial translocation) and from the adipose tissue (i.e., adipocytokines) could interact with both parenchymal and non-parenchymal liver cell populations; in turn, liver inflammation, hepatic insulin resistance, and local oxidative stress can 
affect other organs. This section aims to summarize the most relevant interactions between liver cells and extra-hepatic organs contributing to NAFLD progression (Figure 4).

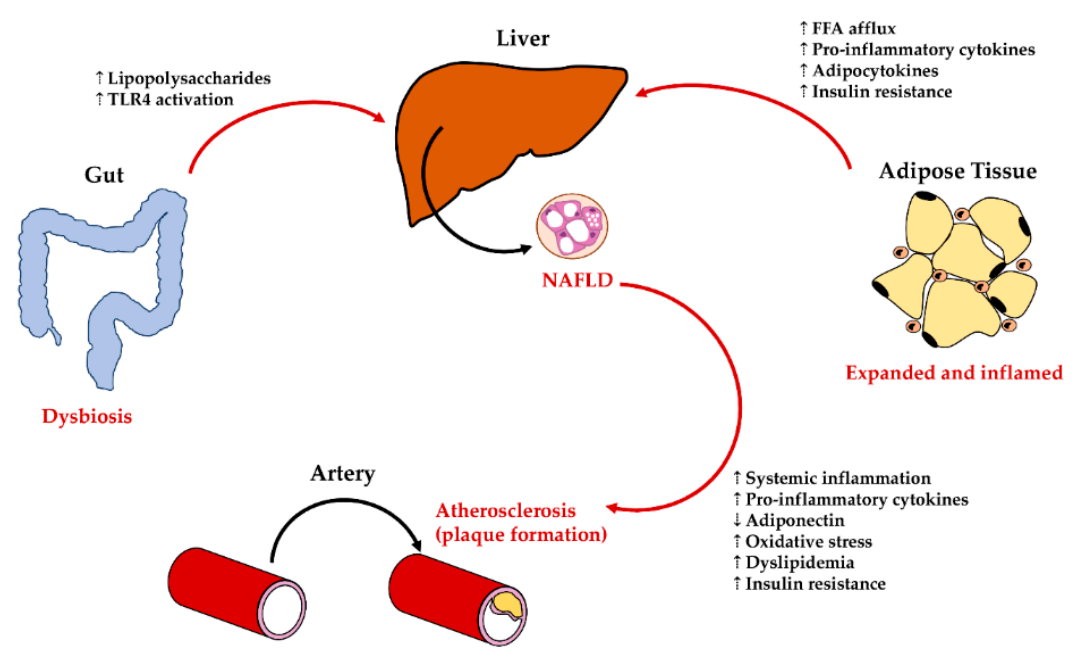

Figure 4. Interaction of liver damage with extra-hepatic organs. NAFLD is influences by interaction with other organs/tissues. Adipose tissue disarrangement (expansion/inflammation) induces increased Free Fatty Acid (FFA) afflux to the liver and insulin resistance; moreover, it releases several pro-inflammatory cytokines and modifies the adipocytokine balance. Dysbiosis in the gut results in translocation of endotoxins (i.e., lipopolysaccharides) to the liver and the subsequent activation of the Toll-like Receptor (TLR) pathway in the liver. In turn, liver with NAFLD/NASH can influence atherosclerosis (plaque formation) by several mechanisms, including, but not limited to, systemic inflammation and oxidative stress increase.

\subsection{Liver-Adipose Tissue Axis: Influences on Liver Cells in NAFLD}

The adipose tissue is considered an immuno-metabolic organ, able to store free fatty acids (FFAs) and maintain the metabolic rate [199]. In particular, visceral adipose tissue is also characterized by the secretion of regulatory cytokines (i.e., adipocytokines) [200,201]. The term adipocytokines include a variety of peptides primarily identified in the adipose tissue and produced by adipocytes (e.g., adiponectin, resistin, leptin) or by local macrophages (e.g., TNF- $\alpha$, IL-6), which play a role in modulating insulin resistance and inflammatory responses [200]. Obesity is characterized by the excessive accumulation of lipids in the adipose tissue, which promotes the development of insulin resistance and sustains a chronic pro-inflammatory state within adipose tissue [202,203].

Progressive adipose tissue dysfunction and insulin resistance represent key events in NASH development, supporting the existence of an adipose tissue-liver crosstalk $[183,204]$. Adipocyte hypertrophy and fibrosis can induce the shift of FFAs to the liver, contributing to hepatic steatosis and to NAFLD progression [205]. In this context, the increased flux of FFAs to the liver contributes to lipotoxicity in hepatocytes, leading to NASH [206,207]; in keeping, diseased hepatocytes could activate Kupffer cells through pattern recognition receptors (e.g., TLRs) and induce local pro-inflammatory cytokine release. Furthermore, adipose tissue could influence hepatic damage through its secretion of pro-inflammatory cytokines, contributing to low-grade systemic inflammation and insulin resistance [183]. The liver itself has been proven to be a source of adipocytokines [110,137,166,208].

Studies in adult obese subjects suggest that macrophage number in adipose tissue is associated with the severity of hepatic inflammation and fibrosis [209-211]. Accordingly, bariatric surgery reduces adipose tissue inflammation and, concomitantly, was shown to determine the improvement of liver histology [166]; this latter is associated with macrophage pool modifications and with a re-shaping of liver and adipose tissue adipocytokine profile [166,212]. 


\subsection{Liver-Gut Axis: Influences on Liver Damage in NAFLD}

Growing evidence supports an important role for the gut-liver axis in the pathogenesis of NAFLD and NASH [183]. A small intestine bacterial overgrowth contributing to increased serum endotoxemia has been described in NAFLD, with Escherichia Coli being the most abundant bacterium [213]. Experimental studies in animals defined the role of lipopolysaccharides (LPS) from gut microbiota in favoring the occurrence of NASH; the administration of non-lethal doses of endotoxins resulted in FAs accumulation in the liver and steatohepatitis [214]. Moreover, the administration of probiotics or antibiotics in animal models of NAFLD reduced inflammation and liver injury [215].

The mechanistic interplay between LPS and liver cell compartments in subjects affected by NAFLD is less clear. Studies in rodents individuate the LPS-TLR4 signaling as crucial in the gut contribution to NAFLD pathogenesis. Macrophages among other cells are potently activated by endotoxin through the TLR4 pathway. However, after infusion into portal vein, LPS is taken up by hepatocytes and secreted into the bile canalicular system [216,217]; LPS is not fully metabolized by liver cells and it is in fact detected in the human peripheral circulation [218]. A recent study indicates that hepatocyte LPS localization in NAFLD patients is associated to liver histologic damage, LPS engulfment by hepatocytes with impaired ability to LPS clearance as a main trigger of the liver inflammatory process [184]. Furthermore, hepatic LPS content can activate TRL4/NF-kB pathway in local cells, including HpSC, macrophages and platelets, enhancing vicious interactions among resident and recruited cells at the basis of NASH progression [184].

\subsection{Liver-Cardiovascular System Interplay in NAFLD}

The interplay between liver and cardiovascular system has been hypothesized based on the recent evidence in the increased cardiovascular risk in NAFLD patients [6].

In multiple large meta-analyses, patients with NAFLD showed a higher risk of cardiovascular disease events than those without NAFLD [219-221]. Severity of liver disease (i.e., NASH diagnosis) appeared to be associated with an increase in cardiovascular events [219-221]. Moreover, NAFLD was associated to cardiovascular risk factors, as hypertension and atherosclerosis. Particularly, subclinical and clinical atherosclerosis have been associated to NAFLD, independently to other known risk factors [6]. Less is known regarding pathogenetic mechanisms, linking the liver and the cardiovascular diseases.

NAFLD increases the risk of developing cardiovascular disease through numerous proposed pathophysiological mechanisms [6]. As discussed above, NAFLD induces systemic inflammation, hepatic insulin resistance, lipid metabolism alteration, and oxidative stress; the inflamed liver is a source of proinflammatory cytokines and adipocytokines, produced by diseased hepatocytes, HpSCs, and M1-polarized Kupffer cells [222]. Systemic inflammation induces endothelial dysfunction, alters vascular tone, and enhances vascular plaque formation [222]. Hepatic lobular inflammation, independently from steatosis, can alter serum lipid profiles, causing abnormally elevated TG, VLDL, and LDL levels, as well as abnormally decreased HDL levels [223]. Finally, hepatocyte alterations in NAFLD are responsible for insulin resistance and contribute to systemic oxidative stress, which are a risk factor for cardiovascular diseases $[44,222,224]$.

\section{Conclusions}

NAFLD is a chronic liver disease and its global prevalence is constantly increasing. The individuation of drugs for NAFLD represents a current effort for clinical researchers. The individuation of cellular and molecular cross-talks between resident liver cells is crucial to define the progression toward steatohepatitis and fibrosis, conditions that are linked to a worse disease evolution and clinical prognosis. Moreover, NAFLD is associated with several alterations in other systems and organs, including the cardiovascular system, digestive tract organs, and adipose tissue, as well as metabolic and endocrine homeostasis. Therefore, the study of interaction between the liver and other organs is 
important for a systemic approach to NAFLD, and crucial—not only from a clinical—but also from a pathogenetic point of view. In this scenario, therapeutic/pharmacological strategies to prevent fibrosis progression requires the individuation of targetable pathways and adequate models that take into account the cellular and humoral microenvironment at the basis of disease progression.

Funding: This research was funded by a research project grant from Sapienza University of Rome (E.G., P.O.). G.C. is further supported by Fondazione per la Ricerca Scientifica Termale (code: 1136) grant.

Conflicts of Interest: The authors declare no conflict of interest.

\section{References}

1. European Association for the Study of the Liver; European Association for the Study of Diabetes; European Association for the Study of Obesity. EASL-EASD-EASO Clinical Practice Guidelines for the management of non-alcoholic fatty liver disease. J. Hepatol. 2016, 64, 1388-1402. [CrossRef]

2. Stefan, N.; Haring, H.U.; Cusi, K. Non-alcoholic fatty liver disease: Causes, diagnosis, cardiometabolic consequences, and treatment strategies. Lancet Diabetes Endocrinol. 2019, 7, 313-324. [CrossRef]

3. Anstee, Q.M.; Reeves, H.L.; Kotsiliti, E.; Govaere, O.; Heikenwalder, M. From NASH to HCC: Current concepts and future challenges. Nat. Rev. Gastroenterol. Hepatol. 2019, 16, 411-428. [CrossRef] [PubMed]

4. Younossi, Z.; Anstee, Q.M.; Marietti, M.; Hardy, T.; Henry, L.; Eslam, M.; George, J.; Bugianesi, E. Global burden of NAFLD and NASH: Trends, predictions, risk factors and prevention. Nat. Rev. Gastroenterol. Hepatol. 2018, 15, 11-20. [CrossRef] [PubMed]

5. Estes, C.; Anstee, Q.M.; Arias-Loste, M.T.; Bantel, H.; Bellentani, S.; Caballeria, J.; Colombo, M.; Craxi, A.; Crespo, J.; Day, C.P.; et al. Modeling NAFLD disease burden in China, France, Germany, Italy, Japan, Spain, United Kingdom, and United States for the period 2016-2030. J. Hepatol. 2018, 69, 896-904. [CrossRef] [PubMed]

6. Stahl, E.P.; Dhindsa, D.S.; Lee, S.K.; Sandesara, P.B.; Chalasani, N.P.; Sperling, L.S. Nonalcoholic fatty liver disease and the heart: JACC state-of-the-art review. J. Am. Coll. Cardiol. 2019, 73, 948-963. [CrossRef] [PubMed]

7. Mann, J.P.; Tang, G.Y.; Nobili, V.; Armstrong, M.J. Evaluations of lifestyle, dietary, and pharmacologic treatments for pediatric nonalcoholic fatty liver disease: A systematic review. Clin. Gastroenterol. Hepatol. 2018. [CrossRef]

8. Nobili, V.; Alisi, A.; Newton, K.P.; Schwimmer, J.B. Comparison of the phenotype and approach to pediatric vs. adult patients with nonalcoholic fatty liver disease. Gastroenterology 2016, 150, 1798-1810. [CrossRef]

9. Skinner, A.C.; Skelton, J.A. Prevalence and trends in obesity and severe obesity among children in the United States, 1999-2012. JAMA Pediatr. 2014, 168, 561-566. [CrossRef]

10. Lin, S.; Nascimento, E.M.; Gajera, C.R.; Chen, L.; Neuhofer, P.; Garbuzov, A.; Wang, S.; Artandi, S.E. Distributed hepatocytes expressing telomerase repopulate the liver in homeostasis and injury. Nature 2018, 556, 244-248. [CrossRef]

11. Wang, B.; Zhao, L.; Fish, M.; Logan, C.Y.; Nusse, R. Self-renewing diploid Axin2(+) cells fuel homeostatic renewal of the liver. Nature 2015, 524, 180-185. [CrossRef] [PubMed]

12. Ang, C.H.; Hsu, S.H.; Guo, F.; Tan, C.T.; Yu, V.C.; Visvader, J.E.; Chow, P.K.H.; Fu, N.Y. Lgr5(+) pericentral hepatocytes are self-maintained in normal liver regeneration and susceptible to hepatocarcinogenesis. Proc. Natl. Acad. Sci. USA 2019, 116, 19530-19540. [CrossRef] [PubMed]

13. Sun, T.; Pikiolek, M.; Orsini, V.; Bergling, S.; Holwerda, S.; Morelli, L.; Hoppe, P.S.; Planas-Paz, L.; Yang, Y.; Ruffner, H.; et al. AXIN2(+) pericentral hepatocytes have limited contributions to liver homeostasis and regeneration. Cell Stem Cell 2020, 26, 97-107. [CrossRef] [PubMed]

14. Planas-Paz, L.; Orsini, V.; Boulter, L.; Calabrese, D.; Pikiolek, M.; Nigsch, F.; Xie, Y.; Roma, G.; Donovan, A.; Marti, P.; et al. The RSPO-LGR4/5-ZNRF3/RNF43 module controls liver zonation and size. Nat. Cell Biol. 2016, 18, 467-479. [CrossRef]

15. Font-Burgada, J.; Shalapour, S.; Ramaswamy, S.; Hsueh, B.; Rossell, D.; Umemura, A.; Taniguchi, K.; Nakagawa, H.; Valasek, M.A.; Ye, L.; et al. Hybrid periportal hepatocytes regenerate the injured liver without giving rise to cancer. Cell 2015, 162, 766-779. [CrossRef]

16. Pu, W.; Zhang, H.; Huang, X.; Tian, X.; He, L.; Wang, Y.; Zhang, L.; Liu, Q.; Li, Y.; Li, Y.; et al. Mfsd2a+ hepatocytes repopulate the liver during injury and regeneration. Nat. Commun. 2016, 7, 13369. [CrossRef] 
17. Chen, F.; Jimenez, R.J.; Sharma, K.; Luu, H.Y.; Hsu, B.Y.; Ravindranathan, A.; Stohr, B.A.; Willenbring, H. Broad distribution of hepatocyte proliferation in liver homeostasis and regeneration. Cell Stem Cell 2020, 26, 27-33. [CrossRef]

18. Schaub, J.R.; Malato, Y.; Gormond, C.; Willenbring, H. Evidence against a stem cell origin of new hepatocytes in a common mouse model of chronic liver injury. Cell Rep. 2014, 8, 933-939. [CrossRef]

19. Kleiner, D.E.; Makhlouf, H.R. Histology of nonalcoholic fatty liver disease and nonalcoholic steatohepatitis in adults and children. Clin. Liver Dis. 2016, 20, 293-312. [CrossRef]

20. Hall, Z.; Bond, N.J.; Ashmore, T.; Sanders, F.; Ament, Z.; Wang, X.; Murray, A.J.; Bellafante, E.; Virtue, S.; Vidal-Puig, A.; et al. Lipid zonation and phospholipid remodeling in nonalcoholic fatty liver disease. Hepatology 2017, 65, 1165-1180. [CrossRef]

21. Kucukoglu, O.; Guldiken, N.; Chen, Y.; Usachov, V.; El-Heliebi, A.; Haybaeck, J.; Denk, H.; Trautwein, C.; Strnad, P. High-fat diet triggers Mallory-Denk body formation through misfolding and crosslinking of excess keratin 8. Hepatology 2014, 60, 169-178. [CrossRef]

22. Ibrahim, S.H.; Hirsova, P.; Gores, G.J. Non-alcoholic steatohepatitis pathogenesis: Sublethal hepatocyte injury as a driver of liver inflammation. Gut 2018, 67, 963-972. [CrossRef] [PubMed]

23. Koliaki, C.; Szendroedi, J.; Kaul, K.; Jelenik, T.; Nowotny, P.; Jankowiak, F.; Herder, C.; Carstensen, M.; Krausch, M.; Knoefel, W.T.; et al. Adaptation of hepatic mitochondrial function in humans with non-alcoholic fatty liver is lost in steatohepatitis. Cell Metab. 2015, 21, 739-746. [CrossRef] [PubMed]

24. Lebeaupin, C.; Vallée, D.; Hazari, Y.; Hetz, C.; Chevet, E.; Bailly-Maitre, B. Endoplasmic reticulum stress signalling and the pathogenesis of non-alcoholic fatty liver disease. J. Hepatol. 2018, 69, 927-947. [CrossRef] [PubMed]

25. Mansouri, A.; Gattolliat, C.H.; Asselah, T. Mitochondrial dysfunction and signaling in chronic liver diseases. Gastroenterology 2018, 155, 629-647. [CrossRef] [PubMed]

26. Musso, G.; Cassader, M.; Paschetta, E.; Gambino, R. Bioactive lipid species and metabolic pathways in progression and resolution of nonalcoholic steatohepatitis. Gastroenterology 2018, 155, 282-302.e288. [CrossRef]

27. Lambert, J.E.; Ramos-Roman, M.A.; Browning, J.D.; Parks, E.J. Increased de novo lipogenesis is a distinct characteristic of individuals with nonalcoholic fatty liver disease. Gastroenterology 2014, 146, 726-735. [CrossRef]

28. Kim, J.Y.; Garcia-Carbonell, R.; Yamachika, S.; Zhao, P.; Dhar, D.; Loomba, R.; Kaufman, R.J.; Saltiel, A.R.; Karin, M. ER stress drives lipogenesis and steatohepatitis via caspase-2 activation of S1P. Cell 2018, 175, 133-145.e115. [CrossRef]

29. Ye, L.; Cao, Z.; Lai, X.; Shi, Y.; Zhou, N. Niacin ameliorates hepatic steatosis by inhibiting de novo lipogenesis via a GPR109A-mediated PKC-ERK1/2-AMPK signaling pathway in C57BL/6 mice fed a high-fat diet. J. Nutr. 2019. [CrossRef]

30. Zhang, M.; Tang, Y.; Tang, E.; Lu, W. MicroRNA-103 represses hepatic de novo lipogenesis and alleviates NAFLD via targeting FASN and SCD1. Biochem. Biophys. Res. Commun. 2020. [CrossRef]

31. Elhafiz, M.; Zhao, G.; Ismail, M.; Xu, D.; Das, D.; Fan, S.; Cheng, N.; Yousef, B.A.; Jiang, Z.; Zhang, L. Imbalanced insulin substrate-1 and insulin substrate-2 signaling trigger hepatic steatosis in vitamin D deficient rats: 8-methoxypsoralen, a vitamin D receptor ligand with a promising anti-steatotic action. Biochim. Biophys. Acta Mol. Cell Biol. Lipids 2020, 158657. [CrossRef] [PubMed]

32. Siculella, L.; Giannotti, L.; Testini, M.; Gnoni, G.V.; Damiano, F. In steatotic cells, ATP-citrate lyase mRNA is efficiently translated through a cap-independent mechanism, contributing to the stimulation of de novo lipogenesis. Int. J. Mol. Sci. 2020, 21, 1206. [CrossRef] [PubMed]

33. Cohen, D.E.; Fisher, E.A. Lipoprotein metabolism, dyslipidemia, and nonalcoholic fatty liver disease. Semin. Liver Dis. 2013, 33, 380-388. [PubMed]

34. Canivet, C.M.; Bonnafous, S.; Rousseau, D.; Leclere, P.S.; Lacas-Gervais, S.; Patouraux, S.; Sans, A.; Luci, C.; Bailly-Maitre, B.; Iannelli, A.; et al. Hepatic FNDC5 is a potential local protective factor against Non-Alcoholic Fatty Liver. Biochim. Biophys. Acta Mol. Basis Dis. 2020, 1866, 165705. [CrossRef] [PubMed]

35. Win, S.; Than, T.A.; Le, B.H.; Garcia-Ruiz, C.; Fernandez-Checa, J.C.; Kaplowitz, N. Sab (Sh3bp5) dependence of JNK mediated inhibition of mitochondrial respiration in palmitic acid induced hepatocyte lipotoxicity. $J$. Hepatol. 2015, 62, 1367-1374. [CrossRef] [PubMed] 
36. Liu, Y.; Xu, W.; Zhai, T.; You, J.; Chen, Y. Silibinin ameliorates hepatic lipid accumulation and oxidative stress in mice with non-alcoholic steatohepatitis by regulating CFLAR-JNK pathway. Acta Pharm. Sin. B 2019, 9, 745-757. [CrossRef]

37. Kojima, S.; Kuo, T.F.; Tatsukawa, H. Regulation of transglutaminase-mediated hepatic cell death in alcoholic steatohepatitis and non-alcoholic steatohepatitis. J. Gastroenterol. Hepatol. 2012, 27, 52-57. [CrossRef]

38. Schuster, S.; Cabrera, D.; Arrese, M.; Feldstein, A.E. Triggering and resolution of inflammation in NASH. Nat. Rev. Gastroenterol. Hepatol. 2018, 15, 349-364. [CrossRef]

39. Sookoian, S.; Pirola, C.J. Meta-analysis of the influence of I148M variant of patatin-like phospholipase domain containing 3 gene (PNPLA3) on the susceptibility and histological severity of nonalcoholic fatty liver disease. Hepatology 2011, 53, 1883-1894. [CrossRef]

40. Romeo, S.; Kozlitina, J.; Xing, C.; Pertsemlidis, A.; Cox, D.; Pennacchio, L.A.; Boerwinkle, E.; Cohen, J.C.; Hobbs, H.H. Genetic variation in PNPLA3 confers susceptibility to nonalcoholic fatty liver disease. Nat. Genet. 2008, 40, 1461-1465. [CrossRef]

41. Huang, Y.; Cohen, J.C.; Hobbs, H.H. Expression and characterization of a PNPLA3 protein isoform (I148M) associated with nonalcoholic fatty liver disease. J. Biol. Chem. 2011, 286, 37085-37093. [CrossRef] [PubMed]

42. BasuRay, S.; Smagris, E.; Cohen, J.C.; Hobbs, H.H. The PNPLA3 variant associated with fatty liver disease (I148M) accumulates on lipid droplets by evading ubiquitylation. Hepatology 2017, 66, 1111-1124. [CrossRef] [PubMed]

43. Valenti, L.; Al-Serri, A.; Daly, A.K.; Galmozzi, E.; Rametta, R.; Dongiovanni, P.; Nobili, V.; Mozzi, E.; Roviaro, G.; Vanni, E.; et al. Homozygosity for the patatin-like phospholipase-3/adiponutrin I148M polymorphism influences liver fibrosis in patients with nonalcoholic fatty liver disease. Hepatology 2010, 51, 1209-1217. [CrossRef] [PubMed]

44. Carpino, G.; Pastori, D.; Baratta, F.; Overi, D.; Labbadia, G.; Polimeni, L.; Di Costanzo, A.; Pannitteri, G.; Carnevale, R.; Del Ben, M.; et al. PNPLA3 variant and portal/periportal histological pattern in patients with biopsy-proven non-alcoholic fatty liver disease: A possible role for oxidative stress. Sci. Rep. 2017, 7, 15756. [CrossRef]

45. Bruschi, F.V.; Tardelli, M.; Herac, M.; Claudel, T.; Trauner, M. Metabolic regulation of hepatic PNPLA3 expression and severity of liver fibrosis in patients with NASH. Liver Int. Off. J. Int. Assoc. Study Liver 2020. [CrossRef]

46. Fu, S.; Watkins, S.M.; Hotamisligil, G.S. The role of endoplasmic reticulum in hepatic lipid homeostasis and stress signaling. Cell Metab. 2012, 15, 623-634. [CrossRef]

47. Zhang, D.; Lin, W.; Liu, Y.; Guo, H.; Wang, L.; Yang, L.; Li, L.; Li, D.; Tang, R. Chronic Microcystin-LR exposure induces abnormal lipid metabolism via endoplasmic reticulum stress in male zebrafish. Toxins (Basel) 2020, 12, 107. [CrossRef]

48. Zeng, X.; Zhu, M.; Liu, X.; Chen, X.; Yuan, Y.; Li, L.; Liu, J.; Lu, Y.; Cheng, J.; Chen, Y. Oleic acid ameliorates palmitic acid induced hepatocellular lipotoxicity by inhibition of ER stress and pyroptosis. Nutr. Metab. (Lond.) 2020, 17, 11. [CrossRef]

49. Hwang, I.; Uddin, M.J.; Pak, E.S.; Kang, H.; Jin, E.J.; Jo, S.; Kang, D.; Lee, H.; Ha, H. The impaired redox balance in peroxisomes of catalase knockout mice accelerates nonalcoholic fatty liver disease through endoplasmic reticulum stress. Free Radic. Biol. Med. 2020, 148, 22-32. [CrossRef]

50. Xiao, T.; Liang, X.; Liu, H.; Zhang, F.; Meng, W.; Hu, F. Mitochondrial stress protein HSP60 regulates ER stress-induced hepatic lipogenesis. J. Mol. Endocrinol. 2020, 64, 67-75. [CrossRef]

51. Borradaile, N.M.; Han, X.; Harp, J.D.; Gale, S.E.; Ory, D.S.; Schaffer, J.E. Disruption of endoplasmic reticulum structure and integrity in lipotoxic cell death. J. Lipid Res. 2006, 47, 2726-2737. [CrossRef] [PubMed]

52. Halbleib, K.; Pesek, K.; Covino, R.; Hofbauer, H.F.; Wunnicke, D.; Hanelt, I.; Hummer, G.; Ernst, R. Activation of the unfolded protein response by lipid bilayer stress. Mol. Cell 2017, 67, 673-684.e678. [CrossRef] [PubMed]

53. Walter, P.; Ron, D. The unfolded protein response: From stress pathway to homeostatic regulation. Science 2011, 334, 1081-1086. [CrossRef] [PubMed]

54. Zhang, K.; Wang, S.; Malhotra, J.; Hassler, J.R.; Back, S.H.; Wang, G.; Chang, L.; Xu, W.; Miao, H.; Leonardi, R.; et al. The unfolded protein response transducer IRE1alpha prevents ER stress-induced hepatic steatosis. EMBO J. 2011, 30, 1357-1375. [CrossRef] [PubMed] 
55. Sepulveda, D.; Rojas-Rivera, D.; Rodriguez, D.A.; Groenendyk, J.; Kohler, A.; Lebeaupin, C.; Ito, S.; Urra, H.; Carreras-Sureda, A.; Hazari, Y.; et al. Interactome screening identifies the ER luminal chaperone Hsp47 as a regulator of the unfolded protein response transducer IRE1alpha. Mol. Cell 2018, 69, 238-252.e237. [CrossRef] [PubMed]

56. Cho, H.K.; Lee, J.Y.; Jang, Y.M.; Kwon, Y.H. Involvement of endoplasmic reticulum stress in palmitate-induced apoptosis in HepG2 cells. Toxicol. Res. 2008, 24, 129-135. [CrossRef]

57. Wang, M.; Kaufman, R.J. Protein misfolding in the endoplasmic reticulum as a conduit to human disease. Nature 2016, 529, 326-335. [CrossRef]

58. Xiong, X.; Wang, X.; Lu, Y.; Wang, E.; Zhang, Z.; Yang, J.; Zhang, H.; Li, X. Hepatic steatosis exacerbated by endoplasmic reticulum stress-mediated downregulation of FXR in aging mice. J. Hepatol. 2014, 60, 847-854. [CrossRef]

59. Lerner, A.G.; Upton, J.P.; Praveen, P.V.; Ghosh, R.; Nakagawa, Y.; Igbaria, A.; Shen, S.; Nguyen, V.; Backes, B.J.; Heiman, M.; et al. IRE1alpha induces thioredoxin-interacting protein to activate the NLRP3 inflammasome and promote programmed cell death under irremediable ER stress. Cell Metab. 2012, 16, 250-264. [CrossRef]

60. Zhang, N.P.; Liu, X.J.; Xie, L.; Shen, X.Z.; Wu, J. Impaired mitophagy triggers NLRP3 inflammasome activation during the progression from nonalcoholic fatty liver to nonalcoholic steatohepatitis. Lab. Investig. J. Tech. Methods Pathol. 2019, 99, 749-763. [CrossRef]

61. Holmström, K.M.; Finkel, T. Cellular mechanisms and physiological consequences of redox-dependent signalling. Nat. Rev. Mol. Cell Biol. 2014, 15, 411-421. [CrossRef] [PubMed]

62. Kotiadis, V.N.; Duchen, M.R.; Osellame, L.D. Mitochondrial quality control and communications with the nucleus are important in maintaining mitochondrial function and cell health. Biochim. Biophys. Acta 2014, 1840, 1254-1265. [CrossRef] [PubMed]

63. Sunny, N.E.; Bril, F.; Cusi, K. Mitochondrial adaptation in nonalcoholic fatty liver disease: Novel mechanisms and treatment strategies. Trends Endocrinol. Metab. 2017, 28, 250-260. [CrossRef] [PubMed]

64. Abdelmegeed, M.A.; Banerjee, A.; Yoo, S.H.; Jang, S.; Gonzalez, F.J.; Song, B.J. Critical role of cytochrome P450 2E1 (CYP2E1) in the development of high fat-induced non-alcoholic steatohepatitis. J. Hepatol. 2012, 57, 860-866. [CrossRef]

65. Boland, M.L.; Oldham, S.; Boland, B.B.; Will, S.; Lapointe, J.M.; Guionaud, S.; Rhodes, C.J.; Trevaskis, J.L. Nonalcoholic steatohepatitis severity is defined by a failure in compensatory antioxidant capacity in the setting of mitochondrial dysfunction. World J. Gastroenterol. WJG 2018, 24, 1748-1765. [CrossRef]

66. Lotowska, J.M.; Sobaniec-Lotowska, M.E.; Bockowska, S.B.; Lebensztejn, D.M. Pediatric non-alcoholic steatohepatitis: the first report on the ultrastructure of hepatocyte mitochondria. World J. Gastroenterol. WJG 2014, 20, 4335-4340. [CrossRef]

67. Satapati, S.; Sunny, N.E.; Kucejova, B.; Fu, X.; He, T.T.; Mendez-Lucas, A.; Shelton, J.M.; Perales, J.C.; Browning, J.D.; Burgess, S.C. Elevated TCA cycle function in the pathology of diet-induced hepatic insulin resistance and fatty liver. J. Lipid Res. 2012, 53, 1080-1092. [CrossRef]

68. Sheldon, R.D.; Meers, G.M.; Morris, E.M.; Linden, M.A.; Cunningham, R.P.; Ibdah, J.A.; Thyfault, J.P.; Laughlin, M.H.; Rector, R.S. eNOS deletion impairs mitochondrial quality control and exacerbates Western diet-induced NASH. Am. J. Physiol. Endocrinol. Metab. 2019, 317, E605-E616. [CrossRef]

69. Hinke, S.A.; Martens, G.A.; Cai, Y.; Finsi, J.; Heimberg, H.; Pipeleers, D.; Van de Casteele, M. Methyl succinate antagonises biguanide-induced AMPK-activation and death of pancreatic beta-cells through restoration of mitochondrial electron transfer. Br. J. Pharmacol. 2007, 150, 1031-1043. [CrossRef]

70. Sanyal, A.J.; Campbell-Sargent, C.; Mirshahi, F.; Rizzo, W.B.; Contos, M.J.; Sterling, R.K.; Luketic, V.A.; Shiffman, M.L.; Clore, J.N. Nonalcoholic steatohepatitis: Association of insulin resistance and mitochondrial abnormalities. Gastroenterology 2001, 120, 1183-1192. [CrossRef]

71. Ikura, Y.; Ohsawa, M.; Suekane, T.; Fukushima, H.; Itabe, H.; Jomura, H.; Nishiguchi, S.; Inoue, T.; Naruko, T.; Ehara, S.; et al. Localization of oxidized phosphatidylcholine in nonalcoholic fatty liver disease: Impact on disease progression. Hepatology 2006, 43, 506-514. [CrossRef] [PubMed]

72. Caldwell, S.H.; Swerdlow, R.H.; Khan, E.M.; Iezzoni, J.C.; Hespenheide, E.E.; Parks, J.K.; Parker, W.D., Jr. Mitochondrial abnormalities in non-alcoholic steatohepatitis. J. Hepatol. 1999, 31, 430-434. [CrossRef]

73. Noureddin, M.; Yates, K.P.; Vaughn, I.A.; Neuschwander-Tetri, B.A.; Sanyal, A.J.; McCullough, A.; Merriman, R.; Hameed, B.; Doo, E.; Kleiner, D.E.; et al. Clinical and histological determinants of nonalcoholic steatohepatitis and advanced fibrosis in elderly patients. Hepatology 2013, 58, 1644-1654. [CrossRef] [PubMed] 
74. Yamada, T.; Murata, D.; Adachi, Y.; Itoh, K.; Kameoka, S.; Igarashi, A.; Kato, T.; Araki, Y.; Huganir, R.L.; Dawson, T.M.; et al. Mitochondrial stasis reveals p62-mediated ubiquitination in parkin-independent mitophagy and mitigates nonalcoholic fatty liver disease. Cell Metab. 2018, 28, 588-604.e585. [CrossRef]

75. Lee, J.; Park, J.S.; Roh, Y.S. Molecular insights into the role of mitochondria in non-alcoholic fatty liver disease. Arch. Pharm. Res. 2019, 42, 935-946. [CrossRef]

76. Zeng, X.; Yang, J.; Hu, O.; Huang, J.; Ran, L.; Chen, M.; Zhang, Y.; Zhou, X.; Zhu, J.; Zhang, Q.; et al. Dihydromyricetin ameliorates nonalcoholic fatty liver disease by improving mitochondrial respiratory capacity and redox homeostasis through modulation of SIRT3 signaling. Antioxid. Redox Signal. 2019, 30, 163-183. [CrossRef]

77. Baker, P.R., 2nd; Friedman, J.E. Mitochondrial role in the neonatal predisposition to developing nonalcoholic fatty liver disease. J. Clin. Investig. 2018, 128, 3692-3703. [CrossRef]

78. Elsheikh, A.; Lavergne, S.N.; Castrejon, J.L.; Farrell, J.; Wang, H.; Sathish, J.; Pichler, W.J.; Park, B.K.; Naisbitt, D.J. Drug antigenicity, immunogenicity, and costimulatory signaling: evidence for formation of a functional antigen through immune cell metabolism. J. Immunol. 2010, 185, 6448-6460. [CrossRef]

79. Marques, P.E.; Oliveira, A.G.; Pereira, R.V.; David, B.A.; Gomides, L.F.; Saraiva, A.M.; Pires, D.A.; Novaes, J.T.; Patricio, D.O.; Cisalpino, D.; et al. Hepatic DNA deposition drives drug-induced liver injury and inflammation in mice. Hepatology 2015, 61, 348-360. [CrossRef]

80. Murphy, M.P. How mitochondria produce reactive oxygen species. Biochem. J. 2009, 417, 1-13. [CrossRef]

81. Bonten, E.J.; Annunziata, I.; d'Azzo, A. Lysosomal multienzyme complex: Pros and cons of working together. Cell. Mol. Life Sci. 2014, 71, 2017-2032. [CrossRef] [PubMed]

82. Tasdemir, E.; Maiuri, M.C.; Tajeddine, N.; Vitale, I.; Criollo, A.; Vicencio, J.M.; Hickman, J.A.; Geneste, O.; Kroemer, G. Cell cycle-dependent induction of autophagy, mitophagy and reticulophagy. Cell Cycle 2007, 6, 2263-2267. [CrossRef] [PubMed]

83. Yin, X.M.; Ding, W.X.; Gao, W. Autophagy in the liver. Hepatology 2008, 47, 1773-1785. [CrossRef] [PubMed]

84. Singh, R.; Kaushik, S.; Wang, Y.; Xiang, Y.; Novak, I.; Komatsu, M.; Tanaka, K.; Cuervo, A.M.; Czaja, M.J. Autophagy regulates lipid metabolism. Nature 2009, 458, 1131-1135. [CrossRef] [PubMed]

85. Li, Z.; Weller, S.G.; Drizyte-Miller, K.; Chen, J.; Krueger, E.W.; Mehall, B.; Casey, C.A.; Cao, H.; McNiven, M.A. Maturation of lipophagic organelles in hepatocytes is dependent upon a Rab10-dynamin-2 complex. Hepatology 2019. [CrossRef]

86. Manco, R.; Clerbaux, L.A.; Verhulst, S.; Bou Nader, M.; Sempoux, C.; Ambroise, J.; Bearzatto, B.; Gala, J.L.; Horsmans, Y.; van Grunsven, L.; et al. Reactive cholangiocytes differentiate into proliferative hepatocytes with efficient DNA repair in mice with chronic liver injury. J. Hepatol. 2019, 70, 1180-1191. [CrossRef]

87. Takahashi, S.S.; Sou, Y.S.; Saito, T.; Kuma, A.; Yabe, T.; Sugiura, Y.; Lee, H.C.; Suematsu, M.; Yokomizo, T.; Koike, M.; et al. Loss of autophagy impairs physiological steatosis by accumulation of NCoR1. Life Sci Alliance 2020, 3. [CrossRef]

88. Wang, M.E.; Singh, B.K.; Hsu, M.C.; Huang, C.; Yen, P.M.; Wu, L.S.; Jong, D.S.; Chiu, C.H. Increasing dietary medium-chain fatty acid ratio mitigates high-fat diet-induced non-alcoholic steatohepatitis by regulating autophagy. Sci. Rep. 2017, 7, 13999. [CrossRef]

89. Yang, L.; Li, P.; Fu, S.; Calay, E.S.; Hotamisligil, G.S. Defective hepatic autophagy in obesity promotes ER stress and causes insulin resistance. Cell Metab. 2010, 11, 467-478. [CrossRef]

90. Koga, H.; Kaushik, S.; Cuervo, A.M. Altered lipid content inhibits autophagic vesicular fusion. FASEB J. 2010, 24, 3052-3065. [CrossRef]

91. Koga, H.; Kaushik, S.; Cuervo, A.M. Inhibitory effect of intracellular lipid load on macroautophagy. Autophagy 2010, 6, 825-827. [CrossRef] [PubMed]

92. Xue, W.; Wang, J.; Jiang, W.; Shi, C.; Wang, X.; Huang, Y.; Hu, C. Caveolin-1 alleviates lipid accumulation in NAFLD associated with promoting autophagy by inhibiting the Akt/mTOR pathway. Eur. J. Pharmacol. 2020, 871, 172910. [CrossRef] [PubMed]

93. Lee, D.H.; Park, J.S.; Lee, Y.S.; Han, J.; Lee, D.K.; Kwon, S.W.; Han, D.H.; Lee, Y.H.; Bae, S.H. SQSTM1/p62 activates NFE2L2/NRF2 via ULK1-mediated autophagic KEAP1 degradation and protects mouse liver from lipotoxicity. Autophagy 2020, 1-25. [CrossRef] [PubMed]

94. Harada, M. Autophagy is involved in the elimination of intracellular inclusions, Mallory-Denk bodies, in hepatocytes. Med. Mol. Morphol. 2010, 43, 13-18. [CrossRef] 
95. Harada, M.; Hanada, S.; Toivola, D.M.; Ghori, N.; Omary, M.B. Autophagy activation by rapamycin eliminates mouse Mallory-Denk bodies and blocks their proteasome inhibitor-mediated formation. Hepatology 2008, 47, 2026-2035. [CrossRef]

96. Mao, Y.; Yu, F.; Wang, J.; Guo, C.; Fan, X. Autophagy: A new target for nonalcoholic fatty liver disease therapy. Hepat. Med. 2016, 8, 27-37. [CrossRef]

97. Wang, Y.; Singh, R.; Xiang, Y.; Czaja, M.J. Macroautophagy and chaperone-mediated autophagy are required for hepatocyte resistance to oxidant stress. Hepatology 2010, 52, 266-277. [CrossRef]

98. Taylor, R.C.; Cullen, S.P.; Martin, S.J. Apoptosis: Controlled demolition at the cellular level. Nat. Rev. Mol. Cell Biol. 2008, 9, 231-241. [CrossRef]

99. McArthur, K.; Kile, B.T. Apoptotic caspases: Multiple or mistaken identities? Trends Cell Biol. 2018, 28, 475-493. [CrossRef]

100. Hatting, M.; Zhao, G.; Schumacher, F.; Sellge, G.; Al Masaoudi, M.; Gabetaler, N.; Boekschoten, M.; Muller, M.; Liedtke, C.; Cubero, F.J.; et al. Hepatocyte caspase-8 is an essential modulator of steatohepatitis in rodents. Hepatology 2013, 57, 2189-2201. [CrossRef]

101. Li, C.P.; Li, J.H.; He, S.Y.; Li, P.; Zhong, X.L. Roles of Fas/Fasl, Bcl-2/Bax, and Caspase-8 in rat nonalcoholic fatty liver disease pathogenesis. Genet. Mol. Res. 2014, 13, 3991-3999. [CrossRef] [PubMed]

102. Zhang, P.; Wang, P.X.; Zhao, L.P.; Zhang, X.; Ji, Y.X.; Zhang, X.J.; Fang, C.; Lu, Y.X.; Yang, X.; Gao, M.M.; et al. The deubiquitinating enzyme TNFAIP3 mediates inactivation of hepatic ASK1 and ameliorates nonalcoholic steatohepatitis. Nat. Med. 2018, 24, 84-94. [CrossRef] [PubMed]

103. Li, Y.; Wang, C.; Lu, J.; Huang, K.; Han, Y.; Chen, J.; Yang, Y.; Liu, B. PPAR delta inhibition protects against palmitic acid-LPS induced lipidosis and injury in cultured hepatocyte L02 cell. Int. J. Med. Sci. 2019, 16, 1593-1603. [CrossRef]

104. Kanda, T.; Matsuoka, S.; Yamazaki, M.; Shibata, T.; Nirei, K.; Takahashi, H.; Kaneko, T.; Fujisawa, M.; Higuchi, T.; Nakamura, H.; et al. Apoptosis and non-alcoholic fatty liver diseases. World J. Gastroenterol. WJG 2018, 24, 2661-2672. [CrossRef]

105. Ribeiro, P.S.; Cortez-Pinto, H.; Sola, S.; Castro, R.E.; Ramalho, R.M.; Baptista, A.; Moura, M.C.; Camilo, M.E.; Rodrigues, C.M. Hepatocyte apoptosis, expression of death receptors, and activation of NF-kappaB in the liver of nonalcoholic and alcoholic steatohepatitis patients. Am. J. Gastroenterol. 2004, 99, 1708-1717. [CrossRef] [PubMed]

106. Feldstein, A.E.; Canbay, A.; Angulo, P.; Taniai, M.; Burgart, L.J.; Lindor, K.D.; Gores, G.J. Hepatocyte apoptosis and fas expression are prominent features of human nonalcoholic steatohepatitis. Gastroenterology 2003, 125, 437-443. [CrossRef]

107. Alkhouri, N.; Alisi, A.; Okwu, V.; Matloob, A.; Ferrari, F.; Crudele, A.; De Vito, R.; Lopez, R.; Feldstein, A.E.; Nobili, V. Circulating soluble fas and fas ligand levels are elevated in children with nonalcoholic steatohepatitis. Dig. Dis. Sci. 2015, 60, 2353-2359. [CrossRef]

108. Ferreira, D.M.; Castro, R.E.; Machado, M.V.; Evangelista, T.; Silvestre, A.; Costa, A.; Coutinho, J.; Carepa, F.; Cortez-Pinto, H.; Rodrigues, C.M. Apoptosis and insulin resistance in liver and peripheral tissues of morbidly obese patients is associated with different stages of non-alcoholic fatty liver disease. Diabetologia 2011, 54, 1788-1798. [CrossRef]

109. Hsieh, S.; Leaderer, B.P.; Feldstein, A.E.; Santoro, N.; McKay, L.A.; Caprio, S.; McConnell, R. Traffic-related air pollution associations with cytokeratin-18, a marker of hepatocellular apoptosis, in an overweight and obese paediatric population. Pediatr. Obes. 2018, 13, 342-347. [CrossRef]

110. Nobili, V.; Carpino, G.; Alisi, A.; Franchitto, A.; Alpini, G.; De Vito, R.; Onori, P.; Alvaro, D.; Gaudio, E. Hepatic progenitor cells activation, fibrosis, and adipokines production in pediatric nonalcoholic fatty liver disease. Hepatology 2012, 56, 2142-2153. [CrossRef]

111. Guy, C.D.; Suzuki, A.; Zdanowicz, M.; Abdelmalek, M.F.; Burchette, J.; Unalp, A.; Diehl, A.M.; NAFLD CRN. Hedgehog pathway activation parallels histologic severity of injury and fibrosis in human nonalcoholic fatty liver disease. Hepatology 2012, 55, 1711-1721. [CrossRef] [PubMed]

112. Kakisaka, K.; Cazanave, S.C.; Werneburg, N.W.; Razumilava, N.; Mertens, J.C.; Bronk, S.F.; Gores, G.J. A hedgehog survival pathway in 'undead' lipotoxic hepatocytes. J. Hepatol. 2012, 57, 844-851. [CrossRef] [PubMed] 
113. Machado, M.V.; Michelotti, G.A.; Pereira Tde, A.; Boursier, J.; Kruger, L.; Swiderska-Syn, M.; Karaca, G.; Xie, G.; Guy, C.D.; Bohinc, B.; et al. Reduced lipoapoptosis, hedgehog pathway activation and fibrosis in caspase-2 deficient mice with non-alcoholic steatohepatitis. Gut 2015, 64, 1148-1157. [CrossRef] [PubMed]

114. Zhao, P.; Sun, X.; Chaggan, C.; Liao, Z.; In Wong, K.; He, F.; Singh, S.; Loomba, R.; Karin, M.; Witztum, J.L.; et al. An AMPK-caspase-6 axis controls liver damage in nonalcoholic steatohepatitis. Science 2020, 367, 652-660. [CrossRef]

115. Mirea, A.M.; Stienstra, R.; Kanneganti, T.D.; Tack, C.J.; Chavakis, T.; Toonen, E.J.M.; Joosten, L.A.B. Mice deficient in the IL-1beta activation genes Prtn3, elane, and Casp1 are protected against the development of obesity-induced NAFLD. Inflammation 2020. [CrossRef]

116. Roskams, T.A.; Theise, N.D.; Balabaud, C.; Bhagat, G.; Bhathal, P.S.; Bioulac-Sage, P.; Brunt, E.M.; Crawford, J.M.; Crosby, H.A.; Desmet, V.; et al. Nomenclature of the finer branches of the biliary tree: Canals, ductules, and ductular reactions in human livers. Hepatology 2004, 39, 1739-1745. [CrossRef]

117. Schmelzer, E.; Zhang, L.; Bruce, A.; Wauthier, E.; Ludlow, J.; Yao, H.L.; Moss, N.; Melhem, A.; McClelland, R.; Turner, W.; et al. Human hepatic stem cells from fetal and postnatal donors. J. Exp. Med. 2007, 204, 1973-1987. [CrossRef]

118. Libbrecht, L.; Desmet, V.; Van Damme, B.; Roskams, T. The immunohistochemical phenotype of dysplastic foci in human liver: Correlation with putative progenitor cells. J. Hepatol. 2000, 33, 76-84. [CrossRef]

119. Spee, B.; Carpino, G.; Schotanus, B.A.; Katoonizadeh, A.; Vander Borght, S.; Gaudio, E.; Roskams, T. Characterisation of the liver progenitor cell niche in liver diseases: Potential involvement of Wnt and Notch signalling. Gut 2010, 59, 247-257. [CrossRef]

120. Overi, D.; Carpino, G.; Cardinale, V.; Franchitto, A.; Safarikia, S.; Onori, P.; Alvaro, D.; Gaudio, E. Contribution of resident stem cells to liver and biliary tree regeneration in human diseases. Int. J. Mol. Sci. 2018, 19, 2917. [CrossRef]

121. Williams, M.J.; Clouston, A.D.; Forbes, S.J. Links between hepatic fibrosis, ductular reaction, and progenitor cell expansion. Gastroenterology 2014, 146, 349-356. [CrossRef] [PubMed]

122. Mancinelli, R.; Olivero, F.; Carpino, G.; Overi, D.; Rosa, L.; Lepanto, M.S.; Cutone, A.; Franchitto, A.; Alpini, G.; Onori, P.; et al. Role of lactoferrin and its receptors on biliary epithelium. Biometals 2018, 31, 369-379. [CrossRef] [PubMed]

123. Alpini, G.; McGill, J.M.; Larusso, N.F. The pathobiology of biliary epithelia. Hepatology 2002, 35, $1256-1268$. [CrossRef] [PubMed]

124. Gaudio, E.; Carpino, G.; Cardinale, V.; Franchitto, A.; Onori, P.; Alvaro, D. New insights into liver stem cells. Dig. Liver Dis. 2009, 41, 455-462. [CrossRef]

125. Espanol-Suner, R.; Carpentier, R.; Van Hul, N.; Legry, V.; Achouri, Y.; Cordi, S.; Jacquemin, P.; Lemaigre, F.; Leclercq, I.A. Liver progenitor cells yield functional hepatocytes in response to chronic liver injury in mice. Gastroenterology 2012, 143, 1564-1575.e1567. [CrossRef]

126. Malato, Y.; Naqvi, S.; Schurmann, N.; Ng, R.; Wang, B.; Zape, J.; Kay, M.A.; Grimm, D.; Willenbring, H. Fate tracing of mature hepatocytes in mouse liver homeostasis and regeneration. J. Clin. Investig. 2011, 121, 4850-4860. [CrossRef]

127. Rodrigo-Torres, D.; Affo, S.; Coll, M.; Morales-Ibanez, O.; Millan, C.; Blaya, D.; Alvarez-Guaita, A.; Rentero, C.; Lozano, J.J.; Maestro, M.A.; et al. The biliary epithelium gives rise to liver progenitor cells. Hepatology 2014, 60, 1367-1377. [CrossRef]

128. Raven, A.; Lu, W.Y.; Man, T.Y.; Ferreira-Gonzalez, S.; O’Duibhir, E.; Dwyer, B.J.; Thomson, J.P.; Meehan, R.R.; Bogorad, R.; Koteliansky, V.; et al. Cholangiocytes act as facultative liver stem cells during impaired hepatocyte regeneration. Nature 2017, 547, 350-354. [CrossRef]

129. Russell, J.O.; Lu, W.Y.; Okabe, H.; Abrams, M.; Oertel, M.; Poddar, M.; Singh, S.; Forbes, S.J.; Monga, S.P. Hepatocyte-specific beta-catenin deletion during severe liver injury provokes cholangiocytes to differentiate into hepatocytes. Hepatology 2019, 69, 742-759. [CrossRef]

130. Lu, W.Y.; Bird, T.G.; Boulter, L.; Tsuchiya, A.; Cole, A.M.; Hay, T.; Guest, R.V.; Wojtacha, D.; Man, T.Y.; Mackinnon, A.; et al. Hepatic progenitor cells of biliary origin with liver repopulation capacity. Nat. Cell Biol. 2015, 17, 971-983. [CrossRef]

131. Deng, X.; Zhang, X.; Li, W.; Feng, R.X.; Li, L.; Yi, G.R.; Zhang, X.N.; Yin, C.; Yu, H.Y.; Zhang, J.P.; et al. Chronic liver injury induces conversion of biliary epithelial cells into hepatocytes. Cell Stem Cell 2018, 23, 114-122.e113. [CrossRef] 
132. Carpino, G.; Cardinale, V.; Folseraas, T.; Overi, D.; Floreani, A.; Franchitto, A.; Onori, P.; Cazzagon, N.; Berloco, P.B.; Karlsen, T.H.; et al. Hepatic stem/progenitor cell activation differs between primary sclerosing and primary biliary cholangitis. Am. J. Pathol. 2018, 188, 627-639. [CrossRef]

133. Lanzoni, G.; Cardinale, V.; Carpino, G. The hepatic, biliary, and pancreatic network of stem/progenitor cell niches in humans: A new reference frame for disease and regeneration. Hepatology 2016, 64, 277-286. [CrossRef]

134. Boulter, L.; Lu, W.Y.; Forbes, S.J. Differentiation of progenitors in the liver: A matter of local choice. J. Clin. Investig. 2013, 123, 1867-1873. [CrossRef]

135. Boulter, L.; Govaere, O.; Bird, T.G.; Radulescu, S.; Ramachandran, P.; Pellicoro, A.; Ridgway, R.A.; Seo, S.S.; Spee, B.; Van Rooijen, N.; et al. Macrophage-derived Wnt opposes Notch signaling to specify hepatic progenitor cell fate in chronic liver disease. Nat. Med. 2012, 18, 572-579. [CrossRef]

136. Kim, K.H.; Chen, C.C.; Alpini, G.; Lau, L.F. CCN1 induces hepatic ductular reaction through integrin alphavbeta(5)-mediated activation of NF-kappaB. J. Clin. Investig. 2015, 125, 1886-1900. [CrossRef]

137. Carpino, G.; Nobili, V.; Renzi, A.; De Stefanis, C.; Stronati, L.; Franchitto, A.; Alisi, A.; Onori, P.; De Vito, R.; Alpini, G.; et al. Macrophage Activation in Pediatric Nonalcoholic Fatty Liver Disease (NAFLD) correlates with hepatic progenitor cell response via Wnt3a pathway. PLoS ONE 2016, 11, e0157246. [CrossRef]

138. Bird, T.G.; Lu, W.Y.; Boulter, L.; Gordon-Keylock, S.; Ridgway, R.A.; Williams, M.J.; Taube, J.; Thomas, J.A.; Wojtacha, D.; Gambardella, A.; et al. Bone marrow injection stimulates hepatic ductular reactions in the absence of injury via macrophage-mediated TWEAK signaling. Proc. Natl. Acad. Sci. USA 2013, 110, 6542-6547. [CrossRef]

139. Jakubowski, A.; Ambrose, C.; Parr, M.; Lincecum, J.M.; Wang, M.Z.; Zheng, T.S.; Browning, B.; Michaelson, J.S.; Baetscher, M.; Wang, B.; et al. TWEAK induces liver progenitor cell proliferation. J. Clin. Investig. 2005, 115, 2330-2340. [CrossRef]

140. Grzelak, C.A.; Martelotto, L.G.; Sigglekow, N.D.; Patkunanathan, B.; Ajami, K.; Calabro, S.R.; Dwyer, B.J.; Tirnitz-Parker, J.E.; Watkins, D.N.; Warner, F.J.; et al. The intrahepatic signalling niche of hedgehog is defined by primary cilia positive cells during chronic liver injury. J. Hepatol. 2014, 60, 143-151. [CrossRef]

141. Wang, X.; Lopategi, A.; Ge, X.; Lu, Y.; Kitamura, N.; Urtasun, R.; Leung, T.M.; Fiel, M.I.; Nieto, N. Osteopontin induces ductular reaction contributing to liver fibrosis. Gut 2014, 63, 1805-1818. [CrossRef]

142. Coombes, J.D.; Swiderska-Syn, M.; Dolle, L.; Reid, D.; Eksteen, B.; Claridge, L.; Briones-Orta, M.A.; Shetty, S.; Oo, Y.H.; Riva, A.; et al. Osteopontin neutralisation abrogates the liver progenitor cell response and fibrogenesis in mice. Gut 2015, 64, 1120-1131. [CrossRef]

143. Liu, Y.; Cao, L.; Chen, R.; Zhou, X.; Fan, X.; Liang, Y.; Jia, R.; Wang, H.; Liu, G.; Guo, Y.; et al. Osteopontin promotes hepatic progenitor cell expansion and tumorigenicity via activation of beta-catenin in mice. Stem Cells 2015. [CrossRef]

144. Richardson, M.M.; Jonsson, J.R.; Powell, E.E.; Brunt, E.M.; Neuschwander-Tetri, B.A.; Bhathal, P.S.; Dixon, J.B.; Weltman, M.D.; Tilg, H.; Moschen, A.R.; et al. Progressive fibrosis in nonalcoholic steatohepatitis: Association with altered regeneration and a ductular reaction. Gastroenterology 2007, 133, 80-90. [CrossRef]

145. Gadd, V.L.; Skoien, R.; Powell, E.E.; Fagan, K.J.; Winterford, C.; Horsfall, L.; Irvine, K.; Clouston, A.D. The portal inflammatory infiltrate and ductular reaction in human nonalcoholic fatty liver disease. Hepatology 2014, 59, 1393-1405. [CrossRef]

146. Wood, M.J.; Gadd, V.L.; Powell, L.W.; Ramm, G.A.; Clouston, A.D. Ductular reaction in hereditary hemochromatosis: The link between hepatocyte senescence and fibrosis progression. Hepatology 2014, 59, 848-857. [CrossRef]

147. Nobili, V.; Alisi, A.; Cutrera, R.; Carpino, G.; De Stefanis, C.; D’Oria, V.; De Vito, R.; Cucchiara, S.; Gaudio, E.; Musso, G. Altered gut-liver axis and hepatic adiponectin expression in OSAS: novel mediators of liver injury in paediatric non-alcoholic fatty liver. Thorax 2015, 70, 769-781. [CrossRef]

148. Lee, U.E.; Friedman, S.L. Mechanisms of hepatic fibrogenesis. Best Pract. Res. Clin. Gastroenterol. 2011, 25, 195-206. [CrossRef]

149. Tsukamoto, H.; Zhu, N.L.; Asahina, K.; Mann, D.A.; Mann, J. Epigenetic cell fate regulation of hepatic stellate cells. Hepatol. Res. 2011, 41, 675-682. [CrossRef]

150. Blaner, W.S.; O’Byrne, S.M.; Wongsiriroj, N.; Kluwe, J.; D’Ambrosio, D.M.; Jiang, H.; Schwabe, R.F.; Hillman, E.M.; Piantedosi, R.; Libien, J. Hepatic stellate cell lipid droplets: A specialized lipid droplet for retinoid storage. Biochim. Biophys. Acta 2009, 1791, 467-473. [CrossRef] 
151. Friedman, S.L. Hepatic stellate cells: Protean, multifunctional, and enigmatic cells of the liver. Physiol. Rev. 2008, 88, 125-172. [CrossRef]

152. Carotti, S.; Morini, S.; Corradini, S.G.; Burza, M.A.; Molinaro, A.; Carpino, G.; Merli, M.; De Santis, A.; Muda, A.O.; Rossi, M.; et al. Glial fibrillary acidic protein as an early marker of hepatic stellate cell activation in chronic and posttransplant recurrent hepatitis C. Liver Transplant. 2008, 14, 806-814. [CrossRef]

153. Carpino, G.; Morini, S.; Ginanni Corradini, S.; Franchitto, A.; Merli, M.; Siciliano, M.; Gentili, F.; Onetti Muda, A.; Berloco, P.; Rossi, M.; et al. Alpha-SMA expression in hepatic stellate cells and quantitative analysis of hepatic fibrosis in cirrhosis and in recurrent chronic hepatitis after liver transplantation. Dig. Liver Dis. 2005, 37, 349-356. [CrossRef]

154. Martinez-Hernandez, A.; Amenta, P.S. The hepatic extracellular matrix. I. Components and distribution in normal liver. Virchows Arch. A Pathol. Anat. Histopathol. 1993, 423, 1-11. [CrossRef]

155. Klaas, M.; Kangur, T.; Viil, J.; Maemets-Allas, K.; Minajeva, A.; Vadi, K.; Antsov, M.; Lapidus, N.; Jarvekulg, M.; Jaks, V. The alterations in the extracellular matrix composition guide the repair of damaged liver tissue. Sci. Rep. 2016, 6, 27398. [CrossRef]

156. Karsdal, M.A.; Nielsen, S.H.; Leeming, D.J.; Langholm, L.L.; Nielsen, M.J.; Manon-Jensen, T.; Siebuhr, A.; Gudmann, N.S.; Ronnow, S.; Sand, J.M.; et al. The good and the bad collagens of fibrosis-Their role in signaling and organ function. Adv. Drug Deliv. Rev. 2017, 121, 43-56. [CrossRef]

157. Karsdal, M.A.; Daniels, S.J.; Holm Nielsen, S.; Bager, C.; Rasmussen, D.G.K.; Loomba, R.; Surabattula, R.; Villesen, I.F.; Luo, Y.; Shevell, D.; et al. Collagen biology and non-invasive biomarkers of liver fibrosis. Liver Int. Off. J. Int. Assoc. Study Liver 2020. [CrossRef]

158. Decaris, M.L.; Li, K.W.; Emson, C.L.; Gatmaitan, M.; Liu, S.; Wang, Y.; Nyangau, E.; Colangelo, M.; Angel, T.E.; Beysen, C.; et al. Identifying nonalcoholic fatty liver disease patients with active fibrosis by measuring extracellular matrix remodeling rates in tissue and blood. Hepatology 2017, 65, 78-88. [CrossRef]

159. Del Ben, M.; Overi, D.; Polimeni, L.; Carpino, G.; Labbadia, G.; Baratta, F.; Pastori, D.; Noce, V.; Gaudio, E.; Angelico, F.; et al. Overexpression of the vitronectin V10 subunit in patients with nonalcoholic steatohepatitis: Implications for noninvasive diagnosis of NASH. Int. J. Mol. Sci. 2018, 19, 603. [CrossRef]

160. Schuppan, D.; Surabattula, R.; Wang, X.Y. Determinants of fibrosis progression and regression in NASH. J. Hepatol. 2018, 68, 238-250. [CrossRef]

161. Bracht, T.; Schweinsberg, V.; Trippler, M.; Kohl, M.; Ahrens, M.; Padden, J.; Naboulsi, W.; Barkovits, K.; Megger, D.A.; Eisenacher, M.; et al. Analysis of disease-associated protein expression using quantitative proteomics-fibulin-5 is expressed in association with hepatic fibrosis. J. Proteome Res. 2015, 14, 2278-2286. [CrossRef]

162. Suppli, M.P.; Rigbolt, K.T.G.; Veidal, S.S.; Heeboll, S.; Eriksen, P.L.; Demant, M.; Bagger, J.I.; Nielsen, J.C.; Oro, D.; Thrane, S.W.; et al. Hepatic transcriptome signatures in patients with varying degrees of nonalcoholic fatty liver disease compared with healthy normal-weight individuals. Am. J. Physiol. Gastrointest. Liver Physiol. 2019, 316, G462-G472. [CrossRef]

163. Pellicoro, A.; Ramachandran, P.; Iredale, J.P. Reversibility of liver fibrosis. Fibrogenes. Tissue Repair 2012, 5, S26. [CrossRef]

164. Munsterman, I.D.; Kendall, T.J.; Khelil, N.; Popa, M.; Lomme, R.; Drenth, J.P.H.; Tjwa, E. Extracellular matrix components indicate remodelling activity in different fibrosis stages of human non-alcoholic fatty liver disease. Histopathology 2018, 73, 612-621. [CrossRef]

165. Sircana, A.; Paschetta, E.; Saba, F.; Molinaro, F.; Musso, G. Recent insight into the role of fibrosis in nonalcoholic steatohepatitis-related hepatocellular carcinoma. Int. J. Mol. Sci. 2019, 20, 1745. [CrossRef]

166. Nobili, V.; Carpino, G.; De Peppo, F.; Caccamo, R.; Mosca, A.; Romito, I.; Overi, D.; Franchitto, A.; Onori, P.; Alisi, A.; et al. Laparoscopic sleeve gastrectomy improves nonalcoholic fatty liver disease-related liver damage in adolescents by reshaping cellular interactions and hepatic adipocytokine production. J. Pediatr. 2018, 194, 100-108.e103. [CrossRef]

167. Harrison, S.A.; Bashir, M.R.; Guy, C.D.; Zhou, R.; Moylan, C.A.; Frias, J.P.; Alkhouri, N.; Bansal, M.B.; Baum, S.; Neuschwander-Tetri, B.A.; et al. Resmetirom (MGL-3196) for the treatment of non-alcoholic steatohepatitis: A multicentre, randomised, double-blind, placebo-controlled, phase 2 trial. Lancet 2019, 394, 2012-2024. [CrossRef] 
168. Younossi, Z.M.; Ratziu, V.; Loomba, R.; Rinella, M.; Anstee, Q.M.; Goodman, Z.; Bedossa, P.; Geier, A.; Beckebaum, S.; Newsome, P.N.; et al. Obeticholic acid for the treatment of non-alcoholic steatohepatitis: interim analysis from a multicentre, randomised, placebo-controlled phase 3 trial. Lancet 2019, 394, 2184-2196. [CrossRef]

169. Della Corte, C.; Carpino, G.; De Vito, R.; De Stefanis, C.; Alisi, A.; Cianfarani, S.; Overi, D.; Mosca, A.; Stronati, L.; Cucchiara, S.; et al. Docosahexanoic acid plus Vitamin D treatment improves features of NAFLD in children with serum Vitamin D deficiency: Results from a single centre trial. PLoS ONE 2016, 11, e0168216. [CrossRef]

170. Nielsen, M.J.; Nedergaard, A.F.; Sun, S.; Veidal, S.S.; Larsen, L.; Zheng, Q.; Suetta, C.; Henriksen, K.; Christiansen, C.; Karsdal, M.A.; et al. The neo-epitope specific PRO-C3 ELISA measures true formation of type III collagen associated with liver and muscle parameters. Am. J. Transl. Res. 2013, 5, 303-315.

171. Nielsen, M.J.; Veidal, S.S.; Karsdal, M.A.; Orsnes-Leeming, D.J.; Vainer, B.; Gardner, S.D.; Hamatake, R.; Goodman, Z.D.; Schuppan, D.; Patel, K. Plasma Pro-C3 (N-terminal type III collagen propeptide) predicts fibrosis progression in patients with chronic hepatitis C. Liver Int. Off. J. Int. Assoc. Study Liver 2015, 35, 429-437. [CrossRef] [PubMed]

172. Boyle, M.; Tiniakos, D.; Schattenberg, J.M.; Ratziu, V.; Bugianessi, E.; Petta, S.; Oliveira, C.P.; Govaere, O.; Younes, R.; McPherson, S.; et al. Performance of the PRO-C3 collagen neo-epitope biomarker in non-alcoholic fatty liver disease. JHEP Rep. 2019, 1, 188-198. [CrossRef] [PubMed]

173. Hou, W.; Janech, M.G.; Sobolesky, P.M.; Bland, A.M.; Samsuddin, S.; Alazawi, W.; Syn, W.K. Proteomic screening of plasma identifies potential noninvasive biomarkers associated with significant/advanced fibrosis in patients with nonalcoholic fatty liver disease. Biosci. Rep. 2020, 40. [CrossRef] [PubMed]

174. Skoien, R.; Richardson, M.M.; Jonsson, J.R.; Powell, E.E.; Brunt, E.M.; Neuschwander-Tetri, B.A.; Bhathal, P.S.; Dixon, J.B.; O’Brien, P.E.; Tilg, H.; et al. Heterogeneity of fibrosis patterns in non-alcoholic fatty liver disease supports the presence of multiple fibrogenic pathways. Liver Int. 2013, 33, 624-632. [CrossRef]

175. Clouston, A.D.; Powell, E.E.; Walsh, M.J.; Richardson, M.M.; Demetris, A.J.; Jonsson, J.R. Fibrosis correlates with a ductular reaction in hepatitis C: roles of impaired replication, progenitor cells and steatosis. Hepatology 2005, 41, 809-818. [CrossRef]

176. Eckert, C.; Klein, N.; Kornek, M.; Lukacs-Kornek, V. The complex myeloid network of the liver with diverse functional capacity at steady state and in inflammation. Front. Immunol. 2015, 6, 179. [CrossRef]

177. Breous, E.; Somanathan, S.; Vandenberghe, L.H.; Wilson, J.M. Hepatic regulatory T cells and Kupffer cells are crucial mediators of systemic T cell tolerance to antigens targeting murine liver. Hepatology 2009, 50, 612-621. [CrossRef]

178. Kuniyasu, Y.; Marfani, S.M.; Inayat, I.B.; Sheikh, S.Z.; Mehal, W.Z. Kupffer cells required for high affinity peptide-induced deletion, not retention, of activated CD8+ T cells by mouse liver. Hepatology 2004, 39, 1017-1027. [CrossRef]

179. Thomson, A.W.; Knolle, P.A. Antigen-presenting cell function in the tolerogenic liver environment. Nat. Rev. Immunol. 2010, 10, 753-766. [CrossRef]

180. Huang, W.; Metlakunta, A.; Dedousis, N.; Zhang, P.; Sipula, I.; Dube, J.J.; Scott, D.K.; O’Doherty, R.M. Depletion of liver Kupffer cells prevents the development of diet-induced hepatic steatosis and insulin resistance. Diabetes 2010, 59, 347-357. [CrossRef]

181. Lanthier, N.; Molendi-Coste, O.; Cani, P.D.; van Rooijen, N.; Horsmans, Y.; Leclercq, I.A. Kupffer cell depletion prevents but has no therapeutic effect on metabolic and inflammatory changes induced by a high-fat diet. FASEB J. 2011, 25, 4301-4311. [CrossRef] [PubMed]

182. Leroux, A.; Ferrere, G.; Godie, V.; Cailleux, F.; Renoud, M.L.; Gaudin, F.; Naveau, S.; Prevot, S.; Makhzami, S.; Perlemuter, G.; et al. Toxic lipids stored by Kupffer cells correlates with their pro-inflammatory phenotype at an early stage of steatohepatitis. J. Hepatol. 2012, 57, 141-149. [CrossRef] [PubMed]

183. Kazankov, K.; Jorgensen, S.M.D.; Thomsen, K.L.; Moller, H.J.; Vilstrup, H.; George, J.; Schuppan, D.; Gronbaek, H. The role of macrophages in nonalcoholic fatty liver disease and nonalcoholic steatohepatitis. Nat. Rev. Gastroenterol. Hepatol. 2019, 16, 145-159. [CrossRef] [PubMed]

184. Carpino, G.; Del Ben, M.; Pastori, D.; Carnevale, R.; Baratta, F.; Overi, D.; Francis, H.; Cardinale, V.; Onori, P.; Safarikia, S.; et al. Increased liver localization of lipopolysaccharides in human and experimental non-alcoholic fatty liver disease. Hepatology 2019. [CrossRef] [PubMed]

185. Wan, J.; Benkdane, M.; Teixeira-Clerc, F.; Bonnafous, S.; Louvet, A.; Lafdil, F.; Pecker, F.; Tran, A.; Gual, P.; Mallat, A.; et al. M2 Kupffer cells promote M1 Kupffer cell apoptosis: A protective mechanism against alcoholic and non-alcoholic fatty liver disease. Hepatology 2014, 59, 130-142. [CrossRef] [PubMed] 
186. Baeck, C.; Wehr, A.; Karlmark, K.R.; Heymann, F.; Vucur, M.; Gassler, N.; Huss, S.; Klussmann, S.; Eulberg, D.; Luedde, T.; et al. Pharmacological inhibition of the chemokine CCL2 (MCP-1) diminishes liver macrophage infiltration and steatohepatitis in chronic hepatic injury. Gut 2012, 61, 416-426. [CrossRef] [PubMed]

187. Miura, K.; Yang, L.; van Rooijen, N.; Ohnishi, H.; Seki, E. Hepatic recruitment of macrophages promotes nonalcoholic steatohepatitis through CCR2. Am. J. Physiol. Gastrointest. Liver Physiol. 2012, 302, G1310-G1321. [CrossRef]

188. Obstfeld, A.E.; Sugaru, E.; Thearle, M.; Francisco, A.M.; Gayet, C.; Ginsberg, H.N.; Ables, E.V.; Ferrante, A.W., Jr. C-C chemokine receptor 2 (CCR2) regulates the hepatic recruitment of myeloid cells that promote obesity-induced hepatic steatosis. Diabetes 2010, 59, 916-925. [CrossRef]

189. Carpino, G.; Renzi, A.; Onori, P.; Gaudio, E. Role of hepatic progenitor cells in nonalcoholic fatty liver disease development: Cellular cross-talks and molecular networks. Int. J. Mol. Sci. 2013, 14, 20112-20130. [CrossRef]

190. Pradere, J.P.; Kluwe, J.; De Minicis, S.; Jiao, J.J.; Gwak, G.Y.; Dapito, D.H.; Jang, M.K.; Guenther, N.D.; Mederacke, I.; Friedman, R.; et al. Hepatic macrophages but not dendritic cells contribute to liver fibrosis by promoting the survival of activated hepatic stellate cells in mice. Hepatology 2013, 58, 1461-1473. [CrossRef]

191. Sunami, Y.; Leithauser, F.; Gul, S.; Fiedler, K.; Guldiken, N.; Espenlaub, S.; Holzmann, K.H.; Hipp, N.; Sindrilaru, A.; Luedde, T.; et al. Hepatic activation of IKK/NFkappaB signaling induces liver fibrosis via macrophage-mediated chronic inflammation. Hepatology 2012, 56, 1117-1128. [CrossRef] [PubMed]

192. Alisi, A.; Carpino, G.; Oliveira, F.L.; Panera, N.; Nobili, V.; Gaudio, E. The role of tissue macrophage-mediated inflammation on NAFLD pathogenesis and its clinical implications. Med. Inflamm. 2017, 2017, 8162421. [CrossRef] [PubMed]

193. Van Hul, N.; Lanthier, N.; Espanol Suner, R.; Abarca Quinones, J.; van Rooijen, N.; Leclercq, I. Kupffer cells influence parenchymal invasion and phenotypic orientation, but not the proliferation, of liver progenitor cells in a murine model of liver injury. Am. J. Pathol. 2011, 179, 1839-1850. [CrossRef] [PubMed]

194. Lumeng, C.N.; Saltiel, A.R. Inflammatory links between obesity and metabolic disease. J. Clin. Investig. 2011, 121, 2111-2117. [CrossRef]

195. Bertolani, C.; Sancho-Bru, P.; Failli, P.; Bataller, R.; Aleffi, S.; DeFranco, R.; Mazzinghi, B.; Romagnani, P.; Milani, S.; Gines, P.; et al. Resistin as an intrahepatic cytokine: Overexpression during chronic injury and induction of proinflammatory actions in hepatic stellate cells. Am. J. Pathol. 2006, 169, 2042-2053. [CrossRef]

196. Marra, F.; Bertolani, C. Adipokines in liver diseases. Hepatology 2009, 50, 957-969. [CrossRef]

197. Beier, J.I.; Guo, L.; von Montfort, C.; Kaiser, J.P.; Joshi-Barve, S.; Arteel, G.E. New role of resistin in lipopolysaccharide-induced liver damage in mice. J. Pharmacol. Exp. Ther. 2008, 325, 801-808. [CrossRef]

198. Nobili, V.; Carpino, G.; Alisi, A.; De Vito, R.; Franchitto, A.; Alpini, G.; Onori, P.; Gaudio, E. Role of docosahexaenoic acid treatment in improving liver histology in pediatric nonalcoholic fatty liver disease. PLOS ONE 2014, 9, e88005. [CrossRef]

199. Ali, A.T.; Hochfeld, W.E.; Myburgh, R.; Pepper, M.S. Adipocyte and adipogenesis. Eur. J. Cell Biol. 2013, 92, 229-236. [CrossRef]

200. Polyzos, S.A.; Kountouras, J.; Mantzoros, C.S. Adipokines in nonalcoholic fatty liver disease. Metabolism 2016, 65, 1062-1079. [CrossRef]

201. Cinti, S. The adipose organ: Morphological perspectives of adipose tissues. Proc. Nutr. Soc. 2001, 60, 319-328. [CrossRef] [PubMed]

202. Ayeser, T.; Basak, M.; Arslan, K.; Sayan, I. Investigating the correlation of the number of diagnostic criteria to serum adiponectin, leptin, resistin, TNF-alpha, EGFR levels and abdominal adipose tissue. Diabetes Metab. Syndr. 2016, 10, S165-S169. [CrossRef] [PubMed]

203. Verboven, K.; Wouters, K.; Gaens, K.; Hansen, D.; Bijnen, M.; Wetzels, S.; Stehouwer, C.D.; Goossens, G.H.; Schalkwijk, C.G.; Blaak, E.E.; et al. Abdominal subcutaneous and visceral adipocyte size, lipolysis and inflammation relate to insulin resistance in male obese humans. Sci. Rep. 2018, 8, 4677. [CrossRef] [PubMed]

204. Sun, K.; Tordjman, J.; Clement, K.; Scherer, P.E. Fibrosis and adipose tissue dysfunction. Cell Metab. 2013, 18, 470-477. [CrossRef] [PubMed]

205. Walker, R.W.; Allayee, H.; Inserra, A.; Fruhwirth, R.; Alisi, A.; Devito, R.; Carey, M.E.; Sinatra, F.; Goran, M.I.; Nobili, V. Macrophages and fibrosis in adipose tissue are linked to liver damage and metabolic risk in obese children. Obesity (Silver Spring) 2014, 22, 1512-1519. [CrossRef]

206. Manco, M.; Bottazzo, G.; DeVito, R.; Marcellini, M.; Mingrone, G.; Nobili, V. Nonalcoholic fatty liver disease in children. J. Am. Coll. Nutr. 2008, 27, 667-676. [CrossRef] 
207. Wilson-Perez, H.E.; Chambers, A.P.; Ryan, K.K.; Li, B.; Sandoval, D.A.; Stoffers, D.; Drucker, D.J.; Perez-Tilve, D.; Seeley, R.J. Vertical sleeve gastrectomy is effective in two genetic mouse models of glucagon-like Peptide 1 receptor deficiency. Diabetes 2013, 62, 2380-2385. [CrossRef]

208. Sookoian, S.; Gianotti, T.F.; Rosselli, M.S.; Burgueno, A.L.; Castano, G.O.; Pirola, C.J. Liver transcriptional profile of atherosclerosis-related genes in human nonalcoholic fatty liver disease. Atherosclerosis 2011, 218, 378-385. [CrossRef]

209. Cancello, R.; Tordjman, J.; Poitou, C.; Guilhem, G.; Bouillot, J.L.; Hugol, D.; Coussieu, C.; Basdevant, A.; Bar Hen, A.; Bedossa, P.; et al. Increased infiltration of macrophages in omental adipose tissue is associated with marked hepatic lesions in morbid human obesity. Diabetes 2006, 55, 1554-1561. [CrossRef]

210. Tordjman, J.; Divoux, A.; Prifti, E.; Poitou, C.; Pelloux, V.; Hugol, D.; Basdevant, A.; Bouillot, J.L.; Chevallier, J.M.; Bedossa, P.; et al. Structural and inflammatory heterogeneity in subcutaneous adipose tissue: Relation with liver histopathology in morbid obesity. J. Hepatol. 2012, 56, 1152-1158. [CrossRef]

211. Tordjman, J.; Poitou, C.; Hugol, D.; Bouillot, J.L.; Basdevant, A.; Bedossa, P.; Guerre-Millo, M.; Clement, K. Association between omental adipose tissue macrophages and liver histopathology in morbid obesity: Influence of glycemic status. J. Hepatol. 2009, 51, 354-362. [CrossRef] [PubMed]

212. D’Incao, R.B.; Tovo, C.V.; Mattevi, V.S.; Borges, D.O.; Ulbrich, J.M.; Coral, G.P.; Ramos, M.J.; Meinhardt, N.G. Adipokine levels versus hepatic histopathology in bariatric surgery patients. Obes. Surg. 2017, 27, 2151-2158. [CrossRef] [PubMed]

213. Kapil, S.; Duseja, A.; Sharma, B.K.; Singla, B.; Chakraborti, A.; Das, A.; Ray, P.; Dhiman, R.K.; Chawla, Y. Small intestinal bacterial overgrowth and toll-like receptor signaling in patients with non-alcoholic fatty liver disease. J. Gastroenterol. Hepatol. 2016, 31, 213-221. [CrossRef] [PubMed]

214. Dickerson, R.N.; Karwoski, C.B. Endotoxin-mediated hepatic lipid accumulation during parenteral nutrition in rats. J. Am. Coll. Nutr. 2002, 21, 351-356. [CrossRef]

215. Ferolla, S.M.; Armiliato, G.N.; Couto, C.A.; Ferrari, T.C. Probiotics as a complementary therapeutic approach in nonalcoholic fatty liver disease. World J. Hepatol. 2015, 7, 559-565. [CrossRef]

216. Mimura, Y.; Sakisaka, S.; Harada, M.; Sata, M.; Tanikawa, K. Role of hepatocytes in direct clearance of lipopolysaccharide in rats. Gastroenterology 1995, 109, 1969-1976. [CrossRef]

217. Bikhazi, A.B.; Jurjus, A.R.; Kamal, M.T.; Al-Housseini, A.M.; Saab, R.N.; Jaroudi, W.A.; Bitar, K.M. Kinetics of lipopolysaccharide clearance by Kupffer and parenchyma cells in perfused rat liver. Comp. Biochem. Physiol. C Toxicol. Pharmacol. 2001, 129, 339-348. [CrossRef]

218. Carnevale, R.; Nocella, C.; Petrozza, V.; Cammisotto, V.; Pacini, L.; Sorrentino, V.; Martinelli, O.; Irace, L.; Sciarretta, S.; Frati, G.; et al. Localization of lipopolysaccharide from Escherichia Coli into human atherosclerotic plaque. Sci. Rep. 2018, 8, 3598. [CrossRef]

219. Mahfood Haddad, T.; Hamdeh, S.; Kanmanthareddy, A.; Alla, V.M. Nonalcoholic fatty liver disease and the risk of clinical cardiovascular events: A systematic review and meta-analysis. Diabetes Metab. Syndr. 2017, 11, S209-S216. [CrossRef]

220. Targher, G.; Byrne, C.D.; Lonardo, A.; Zoppini, G.; Barbui, C. Non-alcoholic fatty liver disease and risk of incident cardiovascular disease: A meta-analysis. J. Hepatol. 2016, 65, 589-600. [CrossRef]

221. Wu, S.; Wu, F.; Ding, Y.; Hou, J.; Bi, J.; Zhang, Z. Association of non-alcoholic fatty liver disease with major adverse cardiovascular events: A systematic review and meta-analysis. Sci. Rep. 2016, 6, 33386. [CrossRef] [PubMed]

222. Francque, S.M.; van der Graaff, D.; Kwanten, W.J. Non-alcoholic fatty liver disease and cardiovascular risk: Pathophysiological mechanisms and implications. J. Hepatol. 2016, 65, 425-443. [CrossRef] [PubMed]

223. Neuschwander-Tetri, B.A. Hepatic lipotoxicity and the pathogenesis of nonalcoholic steatohepatitis: The central role of nontriglyceride fatty acid metabolites. Hepatology 2010, 52, 774-788. [CrossRef] [PubMed]

224. Cusi, K. Role of obesity and lipotoxicity in the development of nonalcoholic steatohepatitis: Pathophysiology and clinical implications. Gastroenterology 2012, 142, 711-725.e716. [CrossRef] [PubMed]

(C) 2020 by the authors. Licensee MDPI, Basel, Switzerland. This article is an open access article distributed under the terms and conditions of the Creative Commons Attribution (CC BY) license (http://creativecommons.org/licenses/by/4.0/). 